\title{
LOS JUDIOS MURCIANOS A FINES DEL SIGLO XIV Y COMIENZOS DEL XV
}

Por

JUAN TORRES FONTES 


\section{LAS JUDERIAS DE MURCIA Y ORIHUELA EN 1391}

Del desarrollo de la vida en Murcia en el año 1391 no quedan muchos testimonios, pues las Actas capitulares de este año faltan, y con lo que contamos no es suficiente para poder llegar a conclusiones definitivas. Sucede también que la confrontación y enfrentamiento de dos facciones de la oligarquía murciana con anterioridad y participación de la totalidad de la población en la serie de hechos que se manifiestan de formas muy diversas, incide también en su momento en el problema judio y al parecer fue la causa fundamental de que la judería murciana no sufriera daño alguno.

La decidida actitud del concejo murciano, no sólo amparando la judería, sino reclamando de inmediato bienes de judíos vecinos de la ciudad que habian sido embargados, robados o desaparecidos en distintos lugares de la gobernación valenciana de Orihuela, así como algunas cartas, también de exposición de agravios a distintas localidades murcianas que seguían la facción del adelantado Fajardo, permiten apreciar tres hechos bien perceptibles: los sucesos de Valencia, muertes, robos y forzosas conversiones de los judios de aquella ciudad, asustaron de tal modo a los vecinos de la judería de Murcia que se encontraban en la gobernación de Orihuela, que, los que pudieron escapar, emprendieron 
una alocada huida abandonando sus bienes e incluso útiles de trabajo, olvidando deudas no cobradas o salarios no pagados. En segundo lugar, que la mayor parte de los judíos - aunque algunos documentos hablan de su totalidad- que permanecieron en territorio oriolano, hubieron de convertirse a tenor de las circunstancias. En cambio, en Murcia, la ciudad no sólo fue un oasis de paz -como tantas otras veces en su historia - sino que su concejo se preocupó con inusitada urgencia y con insólitas exigencias en reclamar los bienes ocupados a sus vecinos judíos en la gobernación de Orihuela.

¿Por qué esta disparidad de criterios y actuaciones pese a su vecindad, idoneidad y común dependencia de un mismo obispo, cuando éste fue factor decisivo de la postura murciana? La segregación de la parte septentrional del reino de Murcia en beneficio de la Corona de Aragón, dispuesta en Torrellas en los comienzos de la centuria por los diputados designados para acabar la contienda que enfrentaba a Castilla y Aragón, no tuvo iguales consecuencias en el orden eclesiástico. Dualidad política en adelante entre la recién constituida gobernación de Orihuela y el disminuido reino de Murcia, que indirectamente se mantiene en el aspecto espiritual aunque bajo la misma denominación y gobierno de los obispos de Murcia, pues se producirian choques, fricciones y antagonismos mal disimulados con frecuentes sentencias canónicas de los obispos o sus vicarios sobre los rebeldes a las ordenaciones eclesiásticas.

El descontento oriolano era más en cuanto a la salida de sus contribuciones económicas a la Iglesia fuera de la gobernación, que en mantener el respeto y obediencia que se merecian sus prelados; más por tener que comparecer en Murcia - tierra políticamente extraña-, que no por falta del reconocimiento de sus posibles faltas; y, también, más por estar sometidos en el orden eclesiástico a personas castellanas, que no por considerar injustas sus decisiones.

Esta dualidad, que se precisa en todos los órdenes, fomentada políticamente para procurar diferenciar, separar y alejar a gentes con seme- 
jante mentalidad, formas de vida y afinidades étnicas, cuando no ligadas por estrechos lazos familiares, responde a las decisiones que se adoptan en la capital del reino valenciano. A veces sin conocimiento real de los problemas $\mathrm{y}$, a veces también, con evidente perjuicio para los intereses oriolanos. Pero lo fundamental era mantener la separación y en lo po. sible el antagonismo. No obstante, la ruptura de relaciones y ocasionales daños o cautiverios por una y otra parte no alcanzaron por lo general categoria de contienda bélica, a no ser que hubiera intervención de las unás altas autoridades de las dos coronas y declaración pública de guerra entre ambos reinos.

Razones, motivos, causas, decisiones que determinaron frecuentes actitudes dispares sobre un mismo problema, aunque afectara por igual a una y otra ciudad. De aquí que la reacción fuera distinta cuando en 1391 la persecución contra los judíos se extiende con velocidad inusitada por toda la Península. Y lo que sucede en diversas ciudades castellanas, no se produce en Murcia. Y lo que ocurre en muchas poblaciones de la Corona de Aragón, no se repite en Orihuela. Pero las consecuencias fueron distintas en una y otra capital, pese a que dos de las tres personas que fueron decisivas en la actitud murciana, estaban intimamente relacionadas con Orihuela, pues una era el obispo don Fernando de Pedrosa y otra el caballero oriolano don Ramón de Rocafull.

En Murcia fue esencial la presencia y sagaces medidas adoptadas por su obispo, quien contando con la ayuda del concejo y de algunos caba lleros destacados pudo cortar de raíz los comienzos de una agitación. popular encaminada al saqueo de la judería y matanza de los que no declararan de inmediato sus deseos de conversión. La marginación ger • gráfica-política del reino de Murcia respecto a Andalucía y Castilla, iba a permitir que su autoridades, conocedoras de lo que había acontecido en diversas ciudades andaluzas y castellanas, pudieran anticiparse a cualquier intento de acción violenta. La amenaza no se convirtió en peligro y los judíos pudieron mantener y continuar sus habituales formas de vida con entera regularidad y sin tener que efectuar cambio alguno 
Hubo algunos conversos, pero su número no parece haber sido muy grande.

Reacción distinta en Orihuela. Se supo lo que habia ocurrido en la capital del reino valenciano y se temió que algo semejante pudiera producirse en ella. Las disposiciones episcopales de don Fernando de Pedrosa se extendieron también a Orihuela, pero su Consejo no se consideró con fuerza suficiente para poder defenderlos en su integridad. Comenta Bellot que los representantes de la judería fueron a las casas episcopales donde se encontraba el gobernador Olfo de Próxita, el baile general y el consejo de la villa, a quienes solicitaron su protección, recabando su decisión para saber si tenían que ausentarse o podían contar con su ayuda. El Consejo les aseguró de todo mal, advirtiéndoles que «estuviesen quedos" para no provocar el furor del pueblo. La solución final sería la conversión casi en masa; algunos se ausentaron y el Consejo acordó pagar las deudas pendientes de los judíos para evitar que se fomentara el descontento popular o surgiera el propósito de reintegrarse por la fuerza; aunque no todas fueron pagadas.

Cuando en 1392 fue asaltada la juderia de Burgos por «omes rusticos" según afirmaba Enrique III en carta al obispo Pedrosa y «robaron della muy grant partida", el monarca, precavido y temeroso de que se repitieran las violencias del año anterior o se produjeran donde se habían evitado, envió aviso de lo sucedido y elogiando la intervención episcopal al atender la petición del monarca de que defendiera y guardara a los judíos de su obispado, del que dice «vos, con vuestra grand çiençia e buen esfuerço, sabiendo que me faziades en ello serviçio e plazer, avedeslos guardado e defendido, en lo qual esmerastes a me fazer serviçio, por lo qual fio por Dios de vos fazer mucho bien e merçed». La carta, tan expresiva en mostrar el agradecimiento real, tenía por objeto evitar la reproducción de atentados y excesos con los judíos, y solicitaba que extremara su vigilancia, pusiera, de acuerdo con e] concejo, todos los medios que estimaran convenientes para atajar el 
mal y castigaran a quienes realizaran cualquier intento con atal justiçia que, a los que lo oyesen o sopiesen, sea escarmienton.

Pero en la Corte algo se sabía de lo que ocurría por entonces en la ciudad, y la carta real tiene mayor alcance, pues se precisa la necesaria continuidad en la capital del obispo, ya que se tenian noticias de que pensaba ausentarse de Murcia. Enrique III le ruega y prohíbe salir de la ciudad y le manda, caso de hallarse fuera, regresar a ella, con advertencia de que daba orden al concejo de que le impidieran su salida. Tan diáfana y acertada había sido la actitud de don Fernando de Pedrosa que quienes habían informado al rey eran tres destacados vecinos de la aljama murciana: Suleiman Aventuriel, el cirujano don Mayr y Mosé Aventuriel, hijo de don Zag el Calvo, quienes arrostrando peligros, marcharon a Segovia y obtuvieron cartas reales para el obispo y concejo (1). Medidas precautorias y común decisión de que se mantuviera el orden. que evitó el conflicto. Por ello nada pasó en este aspecto, porque otros sucesos ocupaban y preocupaban a todos los murcianos, ya que a todos afectaba.

Tres casos distintos, pero de las mismas fechas, muestran lo sucedido en la gobernación de Orihuela. El primero es el de Yahuda, herrero. Fue requerido por el concejo de Callosa para que instalara herrería en la villa por tiempo de un año, con promesa de que se le pagaría una barchilla de trigo por cada par de bestias herradas, aparte de lo que pudiera obtener en otros trabajos propios de su oficio. Aceptada la propuesta, Yahuda con herramientas propias y otras prestadas marchó a Callosa, donde trabajó a gusto de todos, tanto como para que el concejo le rogara su permanencia un mes hasta que encontraran quien le sustituyera. Pero entonces llegó allí noticia del movimiento antijudío de Valencia y Yahuda, con recelo de ser muerto u obligado a convertirse, huyó a Murcia dejando sus martillos, tenazas, clavazón y otras herramientas. Sus posteriores intentos de recobrar cuanto le pertenecía re-

(1) TonRes Fontes: Murcia medieval. Testimonio documental. Tres obispos $y$ un obispillo, Murgetana, 53, Murcia, 1978, págs. 78-80. 
sultaron inútiles, pues todo le había sido embargado en nombre del lugarteniente de baile de Orihuela.

Con razonada exposición de cuanto había relatado su vecino, el concejo de Murcia escribía en septiembre de 1391 al de Orihuela solicitando la devolución de sus bienes, pidiendo información de las causas que habían motivado el embargo, ya que Yahuda no encontraba en su actividad anterior en Callosa hecho alguno o deuda incumplida, mostrándose, además, dispuesto a satisfacer cualquier pequeña deuda que pudiera tener (2).

El segundo fue el de Yanto Aseo, orfebre. Vivía en Elche y el concejo de Alicante solicitó sus servicios, prometiéndole pagar bien su labor. Aceptó y marchó a Alicante llevando consigo sus herramientas y otros útiles de su oficio. Allí estuvo tres meses, trabajando para el concejo, según declaraba, noche y día sin descanso, en hechuras singulares, como fue el hacer imágenes y figuras conforme se lo ordenaban los maestros entendido en su arte, que "diz que avian de sacar agua encantada que estava açerca del camino de la dicha villa de Alicante». Y con la promesa de que si se lograba obtener dicha agua le darían cincuenta florines; caso de que el resultado fuera negativo, le abonarían bien su trabajo. Pero entonces tuvo lugar el asalto de la judería de Valencia, y Yanto Aseo no queriendo dejar su religión y temiendo por su vida, abandonó precipitadamente Alicante y acudió a refugiarse en Murcia, de cuya judería se hizo vecino. Ya en ella, asegurada su vida y creencias, procuró recobrar lo abandonado y perdido: dos hopas (una de Malinas, celeste, y otra de más baja calidad); seis cabezales de lana y dos sábanas, manteles, etc., así como sus herramientas, salarios no devengados, plata, plomo y alambre utilizado en su trabajo.

El concejo de Murcia pidió al de Alicante que atendiera la reclamación de Yanto Aseo, quien aparte de la devolución de sus ropas y útiles

(2) Apéndice, doc. 2. 
de trabajo, solicitaba el pago de sus haberes y el valor de los metales empleados en la confección de las figuras y que estimaba en treinta florines, si bien dejaba su aprecio en el baile y componentes del concejo alicantino: "lo que en vuestras conçiencias vos entendieredes que mereçe por su trabajo del tienpo que vos sirvio e de lo suyo que y puson (3).

Más complicado es el caso de Zag Cohen, especiero. Natural de Murcia y en buena situación económica, en los primeros dias de julio de 1391 emprendía viaje a Valencia con propósito de comprar especias y vender tres cargas de lino espadado, que pesaban treinta y seis arrobas. El matrimonio Cohen llevaban también consigo rica ropa de seda, lana y lino "para se onrrar con ellas". Al llegar a Orihuela se hospedaron en casa de los padres de la señora Cohen, donde pasaron unos días de descanso. Inesperadamente y con el sobresalto consiguiente, les llegó aviso de los sucesos de Valencia, motivo por el que los judios de Orihuela "se tornaron christianos", y Zag con su mujer regresaron precipitadamente a Murcia dejando cuanto llevaban en caso de su suegro. Pero también éste, Samuel Alory, optó por continuar en su religión, por lo que tuvo que salir a escondidas, entregando todos los bienes de su yerno a un amigo, nuevo cristiano. Pero éste, como tantos otros, para demostrar su buena disposición, no ocultó cuanto tenía escondido y de inmediato todo fue embargado por una deuda de treinta florines que se dijo tenia Samuel Alory. Ni el procurador que Zag Cohen envió a Orihuela, con testimonios suficientes para demostrar la propiedad de cuanto había sido embargado a nombre de su suegro, ni dos cartas que remitió el concejo de Murcia con igual propósito, tuvieron efectividad por entonces (4).

\footnotetext{
(3) Apéndice, doc. 3.

(4) Vid. Riesgo de Zag Cohen y ventura de Alfonso Yañez Cohen, en publicación.
} 


\section{CONTINUIDAD URBANA DE LA JUDERIA}

Por conveniencia propia, por la protección a que estaba obligado a proporcionarles y que recoge en las Partidas, Alfonso X, al llevar a efecto el repartimiento de la ciudad de Murcia, dio orden de que aningund judio en la çibdat de Murcia non more entre christianos, mas que ayan su juderia apartada a la puerta de Orihuela, en aquel logar que los partidores les dieron por nuestro mandado» (5).

Por los mismos motivos no iba a variar su emplazamiento en el transcurso de los dos siglos siguientes hasta su expulsión. Para los judíos resultaba necesario y proporcionaba mayor seguridad vivir apartados, dentro de los muros de la ciudad, porque personas y bienes quedaban a salvo de las vejaciones y robos que hubieran sufrido con excesiva frecuencia de vivir entre cristianos; así, sin interferir en las costumbres y formas de vida de los demás vecinos, ellos podían a su vez mantener modos y usos conforme a su religión y tradiciones más peculiares, aunque para su cotidiano vivir sí tenían que salir de su recinto y participar en la actividad urbana con sus variadas ocupaciones, atendiendo sus pequeñas tiendas, oficinas y talleres o en el ejercicio de sus profesiones, desde el médico hasta el corredor, aunque al ponerse el sol volvieran a encerrarse en la judería.

Pero en épocas florecientes y prósperas, cuando las discriminaciones a actitudes hostiles antijudaicas se atenuaban o desaparecían, fueron muchos los judíos que adquirieron casas, tanto en el sector urbano donde quedaba ubicada la judería, como en zonas más apartados. El incremento demográfico y de medios económicos, así como la falta de muros de separación con los cristianos, facilitaba la adquisición de casas junto a la judería, por lo que gradualmente se fue ampliando el primitivo espacio urbano que les había sido asignado en 1266. Por ello, resulta difícil la delimitación de la judería, ya que las puertas de entrada sólo

(5) TORRES FONTES: Los judios murcianos en el siglo XIII, Murgetana, 18, Murcia, 1962, págs. 5-20. 
cerraban calles unas veces, o calle tan solo en otras, y los intentos que se han hecho para determinar el área que abarcab’ en distintas épocas, no han logrado obtener un resultado convincente.

Si es significativo conocer que comprendía un amrlio sector de la muralla que enfajaba a la ciudad, sin que este dominio de los adarbes pudiera en ningún momento suponer peligro para la seguridad de la capital, puesto que a ellos era a quien más podría afectar cualquier ocupación extraña o brusco cambio en el gobierno del concejo. En cambio, cabe pensar que en algún momento esta vecindad pudiera facilitar la huida o furtiva entrada de algún judío en su arrabal.

Dos disposiciones, alejadas una de otra en unos quince años, son indicativas de la actitud concejil y de la situación en que se hallaban los judíos murcianos en uno y otro momento. En 1397, alejado ya el peligro de que se repitieran por entonces las cruentas persecuciones contra ellos, el concejo hubo de llamarles la atención al tener conocimiento de que habían derribado parte de la muralla y siete almenas del adarbe mayor fueron a tierra, quedando sólo una de ellas entera. Los regidores, informados de lo ocurrido, y culpándoles de negligencia, dieron orden de que lo restauraran a su costa y dejaran la muralla en el estado de seguridad en que debía mantenerse. Y, un mes más tarde, otro acuerdo concejil hace referencia al estado de abandono y suciedad en que se encontraba la barbacana, tanto en la parte que correspondía a la judería como a otras zonas cristianas, pues utilizadas como estercoleros, perjudicaba a los adarbes al ocasionar la destrucción de las almenas, sometidas a cargas y presión indebidas, al mismo tiempo que impedían el paso franco por ellas. De aquí que el concejo mandara a los jurados que se informaran y obligara a los causantes a sacar las basuras y estiércol con objeto de que quedaran libres y desembargadas para el paso de ronda (6).

Situación distinta es la que se plantea en 1411. En la ordenanza

(6) En 14 de julio y 15 de agosto de 1397. 
murciana redactada por las «palabras» de San Vicente Ferrer se exige a los judíos vivir en la judería y prohíbe que tuvieran obradores o tiendas de venta fuera de ella, dando plazo de treinta días para su cumplimiento; de igual forma se vedaba a los cristianos vender pan y hortalizas en las plazas de la juderia, indicando que debían hacerlo fuera en la llamada plaza de Almenara, lugar propicio para que a ella pudieran acudir cristianos y judíos (7). Prohibición que se reitera de forma general por los regentes de Juan II en su ordenanza contra judíos y moros al año siguiente.

Y para cumplimiento de esta disposición, de impedir que los judíos vivieran fuera de su recinto y al mismo tiempo delimitarlo, el 2 de enero de 1413 se insiste ya directamente a Murcia, designando de acuerdo con dicha ordenanza a Juan Sánchez Manuel y Fernán Calvillo para llevar a cabo sobre el terreno la separación y diferenciación que consideraran adecuada y conveniente. Delimitación que debía proporcionar un "círculo aparte», en que todas las calles que daban a la ciudad quedarían cerradas y desaparecer sus puertas, con excepción de una, habilitada para entrada y salida, con cierre nocturno. Pero los dos destacados nobles murcianos entendieron las cosas a su manera y al parecer con unos propósitos totalmente contrarios al espíritu de la disposición y de lo que se les encomendaba, pues en lugar de cerrar calles y puertas, quitaron las dos que había y ordenaron a los judíos desalojar y abandonar la judería.

Decisión que provocó la inmediata reacción concejil, oponiéndose a tan insensata medida que exponia a los judios a ser robados y destruidos; los regidores requirieron a los comisionados reales a que repusieran las puertas y no innovaran cosa alguna hasta que el rey, contestando al escrito que le enviaban informándole de cuanto habían hecho y podía suceder, decidiera lo que considerara más conveniente. No con-

(7) TORRES Fontes: Moros, judios y conversos en la regencia de don Fernando de Antequera, Buenos Aires, 1960, «Cuadernos de Historia de España», XXXIXXXII, págs. $60-97$.

66 
tentos con esto, al mismo tiempo dieron orden a los alcaldes, alguacil y jurados que si Pérez Calvillo y Sánchez Manuel no tornaban las puertas a su sitio, lo hicieran ellos, con objeto de que la judería quedara asegurada (8).

Acuerdo concejil que salvaguardaba una vez más a los judíos de las tropelías que pudieran cometerse contra ellos y que responde a unas relaciones normalmente buenas y consideradas, siempre generosas por parte del concejo y que con su disposición decidía, también otra vez, la continuidad en el mismo lugar de la judería, o como ellos decían, que siguiera "çercada e situada desde que Murçia es de christianos".

\section{LA PROTECCION CONCEJIL}

La actitud del concejo murciano fue siempre favorable a los judíos que vivían en la ciudad. Sus acuerdos en todo momento estuvieron encaminados a proteger y amparar a quienes, como vecinos, tenía el deber de defender. $Y$ lo hicieron con rectitud y arrostrando dificultades, pues fue siempre norma concejil el que se cumplieran las disposiciones forales, reales y sus propias ordenaciones, si bien alguna que otra vez, individualmente, regidores o alcaldes no respondieron a lo que estaban obligados. Tampoco significa en ningún momento trato de favor, sino aplicación de acuerdos propios o cumplimiento de cartas reales y, a falta de ellas, su propósito de continuar manteniendo la justicia como norma de buen gobierno, ya que en ocasiones improvisaron con criterio objetivo y recto, conscientes de su responsabilidad y de la buena imagen que debía presidir todas las decisiones del municipio.

Esta actitud se observa en una serie de hechos, espaciados en el tiempo y que responden frecuentemente a decisiones momentáneas, pero siempre acordes a una forma de actuar y a las circunstancias en que

(8) Apéndice, doc. VII, en Guadalajara, 20-I-1413, y doc. IX, en 14-II-1413. 
se producen. Los ejemplos son abundantes y de algunos de ellos tratamos con mayor amplitud, pero resulta conveniente sintetizarlos para mejor valorar su alcance en el transcurso de este conflictivo período que se extiende desde 1390 a 1413. Es así cuando coopera con el obispo Pedrosa para evitar el asalto de la judería en 1391 o en la adopción de previsoras medidas en 1392 . Y parcialmente interviene en 1394 cuando el recaudador Juan Martínez de la Osa, vecino de Garci Muñoz, renunció no sólo a cobrar por entonces el servicio ordenado el año anterior por Enrique III, en que se había asignado a la Morería dos mil cuatrocientos maravedís y seis mil cincuenta a la Judería, sino que se encargó personalmente de gestionar en la Corte la rebaja de estas cantidades (9).

Lo que no deja de tener su contrapartida, como cuando en 1392 fueron encarcelados los más conocidos fieles y cogedores de las alcabalas, acusados de fraude por el recaudador. De aquí la exigencia concejil de que la aljama asegurara y se responsabilizara económicamente de las "malfetrías» que pudieran cometer los menestrales judíos que trabajaban entre cristianos. Pero de igual manera se interesa y preocupa por ıa libertad y después por la devolución de los bienes de los judíos Salomón Aluleig y Mardohay Axcobar (10), asaltados y secuestrados en 1393 por la facción del adelantado Fajardo -entre los que se encontraba un converso- y que, llevados a Molina Seca, maltratados como esclavos, fueron obligados a rescatarse. Mardohay por veinte florines y medio. Y Alulaig, su rescate y pérdidas las cifraba en ochenta y tres florines y medio, que el concejo ordenó les fuera abonado en bienes de los partidarios del adelantado.

(9) En recaudador manifestó que "vee que las dichas aljamas son despobladas e los judios e moros que son agora en la dicha çibdat son muy pobres e menesterosos, que non los quiere nin entiende afincar nin apremiar agora que paguen los dichos maravedis fasta que el vaya al dicho señor rey a le apercibir deste fecho, e lieva procuraçion e poder de las dichas aljamas a le soplicar e pedir por merçed que les faga alguna baxa de los maravedis del dicho serviçio, e que fiava en la merçed del dicho señor rey que les fara merçed porque las dichas aljamas non se despueblen».

(10) TORRES FONTES: Murcia medieval. Testimonio documental, Murcia, 1978, Murgetana, 52, 86-8. 
Igual atención que a los cristianos prestaría a judíos y moros en los años 1395-96, al sufrir Murcia la catastrófica epidemia de peste que ocasionó 6.088 muertos, de los cuales cuatrocientos cincuenta eran judíos. $\mathrm{O}$, cuando informados los regidores que el alcalde Rodrigo Jaimes de Junteron había cohechado treinta florines de ciertos judios de la aljama, por estar acusados dos de ellos de acuñar moneda falsa, reprocharon a los alcaldes del año siguiente de que no hubieran efectuado la pesquisa obligada, por lo que ordenaron a los jurados que supieran la verdad de cuando había sucedido el año anterior; y al averiguar por declaraciones y juramentos tomados a los viejos y veedores de la aljama de lo que había sucedido y de que efectivamente hubo cohecho, aunque sólo de quince florines, decretaron el embargo de los bienes de Junteron.

Ninguna intervención tuvo el concejo en el proceso de dos ricos judíos de Murcia en 1409, en parte como consecuencia de la reanudación de la actividad antijudaica en Castilla y en parte por escandalosa usura. Fue el procurador fiscal y promotor de la justicia real quien denunció el carácter usurario de las entregas de trigo, cebada, paños y dinero que efectuaban Abrahim Alfatex y el especiero Aben Juga por valor de doscientos mil maravedís. Y la acción judicial emprendida por el procurador fiscal obtuvo la aprobación real de que el pleito se viera en la Corte, tanto por ser su lugar de residencia y de oficio, como porque se realizara atendiendo todas las normas legales de citación y plazos, sin que el concejo tuviera relación alguna con este proceso (11).

Resalta igualmente la actitud mantenida por el concejo en 1411. Había tenido lugar en los comienzos de este año la prolongada estancia de San Vicente Ferrer, lo que supuso un gran número de conversiones y la redacción de una ordenanza concejil por influencia del fraile dominico que restringía considerablemente modos y medios de vida de moros y judíos, lo que no fue impedimento para que meses más tarde pusiera coto a las demasías de algunos frailes dominicos que, queriendo

(11) Apéndice, doc. V. 
seguir el ejemplo del santo valenciano, se sobrepasaban en sus sermones en su deseo de que los judios que se mantenian en su fe, a que se les apremiara a una forzosa conversión, de tal forma que les exponía a graves amenazas y posibles daños, heridas o muertes. Y la petición concejil fue atendida por el rey, que en carta de don Fernando de Antequera de 8 de agosto de 1411, prohibía la continuidad de tales actos y actitudes (12).

Al año siguiente, el concejo censuraba públicamente a su alguacil rnayor por su proceder contra los judíos, ya que indebidamente se entrometía en sus costumbres y vida particular, por cuanto no le competía ni tenía autoridad para intervenir dentro de la juderia y menos dictar prohibiciones ofensivas y arbitrarias. $Y$ el concejo se lo advirtió, con orden terminante de no entrar en la judería y de limitarse a ejercer su vigilancia fuera de ella, manteniendo formas y usos como lo habían hecho los alguaciles de los años anteriores (13).

Semejante alcance tiene la intervención concejil contra un extraño concierto hecho por la aljama con el adelantado y el noble Fernán Pérez Calvillo, en virtud del cual todas las querellas y pleitos que se produjeran entre judios serían juzgados y resueltos por ellos. Lo que siendo contrario a la ordenación real, fuero y disposiciones concejiles, los regidores se negaron a admitir e intervinieron tan pronto tuvieron conocimiento de ello, exigiendo a la aljama la entrega de dicho contrato y con la advertencia de su negativa a que se mantuviera tal «encomendación. (14).

Y así en otros muchos casos en que la atención concejo hacia los judios es continua, amplia y generosa, superando en mucho la correspondencia que cabría esperar a esta actitud. Lo fue en 1403 por la prontitud con que atendió la denuncia presentada por don David Aven-

(12) Apéndice, doc. VI.

(13) Apéndice, doc. VII.

(14) Apéndice, doc. X. El 9-II-1415. 
turiel, Samuel Abenaex y Mose Aventuriel como representantes de la aljama, al adoptar el acuerdo de interesar a Juan Sánchez de Ayala, como lugarteniente de adelantado, y a los propios alcaldes en cuanto concernia a sus respectivos oficios, para que se informaran e hicieran justicia de las aferidas que fueron fechas al fijo de don Mose Aventuriel e don Davi Aventuriel de Ucles» (15).

La escasa compenetración entre adelantado y concejo, así como la falta de energía de aquél, propició en 1403 el aumento del número de delitos, tanto en la ciudad como principalmente en la huerta y camino real. Las denuncias contra las fechorias de malhechores y golfines se suceden en este tiempo con una frecuencia realmente sorprendente, por cuanto no tiene paralelo en años anteriores o posteriores. Todo parece explicarse en la falta de autoridad del adelantado y de la eficacia necesaria para frenar o acabar con tales delincuentes. Y los excesos fueron tales y las quejas tan firmes, que Dávalos decidió delegar en el concejo casos de su competencia y le otorgó poder para intervenir en cuanto afectaba a su jurisdicción, como eran los asaltos en el camino real castellano, secuestros y muertes. Cambio de autoridad que posibilitó atender a dos judios que fueron apresados cuando iban a Orihuela y obligados a rescatarse por ciento cincuenta florines, los cuales de inmediato presentaron su denuncia y lograron que los malhechores fueran presos en Orihuela. El concejo murciano escribió pidiendo la entrega de los secuestradores, tanto por haberse cometido el delito en su jurisdicción, como porque uno de los malhechores había participado con otros en el asesinato de un moro de la encomienda santiaguista de Lorquí, también en término de Murcia (16).

El año 1411 fue también otra fecha importante en el que el tema judaico estuvo presente por la misma causa en numerosas manifestaciones de la vida pública. Lo fue por las predicaciones de San Vicente Ferrer y después por los dominicos, creando un ambiente hostil a la

(15) El 25-IX-1403.

(16) En 10-VIII-1403. 
continuidad de la aljama de los judíos; lo sería por las ordenanzas que se promulgan, primero concejil y después real restringiendo las actividades de moros y judíos; las numerosas conversiones y nuevas formas de vida de los bautizados exigieron deliberaciones, acuerdos y atención concejil, que indirectamente repercuten en el común ciudadano; les afecta igualmente en otros muchos aspectos y entre ellos a los que permanecieron en su fe, limitados en oficios, actividad y posibilidades, pero también en cuanto a su seguridad o el simple respeto a personas, pero que no sería por mucho tiempo, pues tanto la decisión concejil primero, como las órdenes posteriores de don Fernando restablecieron las normas del común devenir ciudadano, que proporcionaron seguridad, orden y continuidad en la regulada convivencia.

Sucede entonces el secuestro de cuatro niños judios en la huerta. El interés concejil en defensa de sus vecinos, sin distinción de raza o clase social y que aquí aumenta por tratarse de niños en resolver estos problemas, se manifiesta continuamente en sus acuerdos. Y lo era también en este caso por el hecho en sí, pues los golfines que los secuentraron los habían llevado a territorio oriolano y buscaron al trujamán Berenguer Morrelles para que interviniera y cobrara su rescate. Estuvieron conformes los padres en abonar los ochenta florines que se les exigía, pero los niños no fueron devueltos. Preso el trujamán por el adelantado, el concejo rogó y requirió al de Orihuela que hiciera justicia, ofreciéndole su ayuda para intentar rescatar a los niños y recuperar el dinero entregado.

De igual forma prestó su ayuda a la denuncia hecha por Mosé Cohen de Sevilla, recaudador de las rentas reales, a quien el hijo de un deudor, con quien mantenía pleito por falta de pago de mil maravedís, intentó asesinar en el mercado acon una espada sacada que le avia cometido e corrido e cometía de le ferir o matar si fudiera", pero la intervención de varias personas pudo impedirlo. Y la protesta del judío no era sólo contra el delincuente por su intención de asesinarle, sino de que lo hubiera hecho quebrantando la paz del mercado, garantizada por el rey 
y faltando a todas las promesas y seguridades que días antes había obtenido de su deudor, así como de que el malhechor, refugiado en el monasterio de Santo Domingo, pudiera escapar de la justicia. Pero cuando se llevó a cabo la reconstrucción de los hechos en el mercado ante la insistencia, protestas y quejas de Mosé Cohen, el alcalde miçer Millán rechazó un tanto airado sus acusaciones y amenazas de querellarse ante el rey, manifestando que cuando supo lo ocurrido «fizo prender al fijo de Martin Royz, que lo avia ya mandado ferrar al alguazil dentro del monasterio de Santo Domingo donde aquel estava e que non se entrometiesen en su ofiçio» (17).

\section{LOS CONVERSOS}

Es bien conocido que los sucesos de 1391 produjeron un gran número de conversos y que las predicaciones de San Vicente Ferrer en $1410-11$ y las leyes restrictivas que entonces se promulgan ocasionan también una cifra elevada de nuevos cristianos. E igualmente no es una novedad el que entre unos y otros existe una gran diferencia: temor y miedo que obliga a casi todos a adoptar decisiones forzosas y no sentidas; convencimiento y oportunismo de quienes voluntariamente cambiaron de religión y la aceptaron de forma definitiva, son sus dos consecuencias. Diferencias que percibía con claridad poco antes de 1490 el cronista murciano Diego Rodriguez de Almela: «fueron tornados muchos judíos christianos por miedo, e asi muchos dellos nunca fueron buenos christianos nin los que dellos vinieron, segund lo que agora poco tienpo ha parecido, e los que fueron convertidos por su grado en la predicación que fizo fray Vicente, salieron buenos christianos, mejor que non los que fueron convertidos por fuerça e miedo».

A partir de 1391 se produce una situación un tanto equívoca, conflictiva en ocasiones y que no deja de crear problemas a las autorida-

(17) En 15-I-1411. 
des concejiles. Pasado el peligro y desaparecida la amenaza, fueron muchos los judios que tendieron a reintegrarse a sus anteriores formas de vida, si bien, al no poder renegar de nuevo, buscaron en la convivencia con los que no habían aceptado la conversión, una relación que a veces cra oculta vuelta a sus creencias judaicas. Pero a su lado estaban los que consideraban que su conversión era un paso sin vuelta ni marcha atrás y procuraron el favor de los cristianos viejos y ofrecer una buena imagen entre ellos denunciando las equívocas andanzas de algunos conversos. Tal lo que sucede en Orihuela hacia 1400, donde uno de ellos llamado Remir Alvarez, denunciaba al consejo que los judios de Murcia, pesarosos de la conversión en masa de los judios oriolanos, enviaban agentes propios y que trabajaban en iguales oficios como zapateros, alfayates y tejedores, trataban con ellos ay continuamente les estaban pervirtiendo». Con su denuncia, Remir Alvarez pudo lograr que el consejo prohibiera que los judíos trabajaran junto a los conversos y sólo les autorizara que pudieran efectuar sus labores junto a cristianos viejos. Y Remir Alvarez pronto obtuvo premio a su actuación, pues poco después fue nombrado consejero.

Son escasas las noticias que nos quedan sobre estos conversos de primera hora, lo que por otra parte es natural, toda vez que no tenemos acta oficial ni relación de los que pudieron ser, más aún por cuanto los que lo hicieron pasaron calladamente a integrarse en las filas cristianas, buscando el mejor acomodo posible o subiendo escalones sin intentar encontrar ayuda en el hecho de su conversión para obtener ventajas económicas o puestos de trabajo, como en abundante número io harian en 1411. Varias razones apoyan esta afirmación y se manifiesta especialmente en que los judios que en 1391 cambian de religión no fueron bien vistos por los cristianos, que dudaban de la sinceridad de su conversión, ni por los que se mantuvieron en la judería, que consideraban traidores a los que sinceramente habían abjurado de sus creencias. Porque no reciben ayuda manifiesta ni trato de favor de unos ni de otros. Aún más, parece que en su mayor parte vuelven ocultamente a practicar su anterior religión. 
Esta actitud de los conversos se expone en el acuerdo concejil de 14 de agosto de 1392 «por quanto algunos de los christianos nuevos que solían ser judios, moran cabo la juderia de la çibdat e parteçipan con ellos de dia e de noche, e es fama que comen carne en los dias de viernes e de los sabados, e por les quitar este pecado e herror, ordenaron e mandaron que alguno ni algunos de los christianos nuevos non moren en casas suyas ni alquiladas desde la calle de la Puerta Nueva, assi como va fasta casa de Françisco Pascual e fasta casa de Juan Vilatorta e fasta casa de Bartolome de Oluja, de la parte faza la juderia e de Santa Olalla, ante, que esten e moren dentro en la çibdat o en la Rexaca. E si por ventura les fuese provado que alguno o algunos de los dichos christianos nuevos comiesen e beviesen qualquier dia, que paguen de pena doze maravedis para el alguazil, e otrosi, que alguno ni algunos de los christianos nuevos non entren de noche en la juderia despues de el sol puesto, so la dicha pena de los dichos doze maravedis para el dicho alguazil, e esto que sea pregonado por la çibdat publicamente». Acuerdo que muestra la tolerancia y comprensión concejil, tanto en la mínima pena pecuniaria que se impone, como en continuar permitiendo que durante el dia pudieran seguir frecuentando la judería.

En cambio, la perspectiva de los conversos que sinceramente aceptaron su nueva situación, no parece haber sido muy boyante. El día 1 de agosto de 1396 «paresçio en el dicho conçejo Ruy Perez de Panes, christiano nuevo, e pidio por merçed al dicho conçejo que por quanto el era venido a menester e mengua, de manera que lo non podia pasar, seyendo el ante desto rico e abonado segund que todo este conçejo sabia, por esta razon pedia por merçed al dicho conçejo e ofiçiales e omes buenos que le diesen liçençia para que pudiese enplazar, con tal condiçion quel non fiziese ni le fiziesen fazer justiçia alguna, e que lo ternia en merçed». Los regidores, ciertos de cuanto les exponía, aceptaron su solicitud, la de poder emplazar, pero sin obligación de hacer justicia, de ser sayón.

Pero lo que a este cristiano nuevo repugnaba y su sensibilidad no 
aceptaba, en cambio iba a ser apetecido por otro cristiano nuevo. El puesto de verdugo, necesario e imprescindible en el concepto concejil de la justicia, no tenía muchos pretendientes, por lo que era problema frecuente que los regidores no acababan de resolver. Por ello tuvieron que recurrir a exigencias arbitrarias, como era la prestación forzosa, obligando a judíos, moros y esclavos a desempeñar tal oficio, con protesta de ciudadanos cristianos por ello. El 23 de julio de 1397 afue dicho que en esta çibdat ay grand mengua de sache para que fagan e cunplan la justiçia, que los alcalles de la dicha çibdat e los otros juezes que han de cunplir la justiçia, por lo que cada que an de fazer alguna justiçia que los alcalles que tomavan e toman moros e judios para fazer e cunplir la dicha justiçia. E por ende, el dicho conçejo e ofiçiales e omes buenos entendiendo que moro o judio faziendo la justiçia de christianos que era mucho mal e grand deserviçio de la christiandad, e por quanto Ferrand Alfonso, christiano nuevo, queria e quiere ser sayon, ordenaron e mandaron que le sean dados de los propios del dicho conçejo çient maravedis, e del dia que començare a fazer terçios del año de quatro en quatro meses, e que Ruy Perez de Panes e Pedro Sanchez, enplazadores, que den de cada año al dicho Ferrand Alfonso cada veynte e çinco maravedis por terçios del año».

No debió ser muy útil ni duradero, tanto porque el oficio desgastaba física y moralmente al verdugo, como porque su condición y modo de vida no era precisamente base de vecindad ciudadana ni recomendable para la convivencia y continuidad, por lo que en la relación murciana de verdugos medievales es frecuente su sustitución, más por cese voluntario que obligado. Ya en 1399 se nombra otro sache o sayón, al parecer también converso y de igual procedencia oriolana. Se dijo lo de siempre, que la ciudad estaba menguada de asages» para hacer y cumplir la justicia que dictaban los alcaldes y que Miguel López quería desempeñar el oficio. El nombramiento contaba con una gratificación de cien maravedis anuales, a lo que añadieron que se le mandara hacer y entregar aun palo a señales de nuestro señor el rey e de la çibdat», como símbolo 
público de su oficio y se le contratara un auxiliar aporque lieve de la cuerda al malfechor».

Años más tarde las cosas comienzan a cambiar con mayor rapidez y a partir de 1407 el problema judío surge de nuevo, aunque con un planteamiento distinto, pues se realiza con medios más poderosos y eficaces. Disposiciones, ordenanzas y predicaciones fueron las armas empleadas que afectaron profundamente a las aljamas y especialmente a quienes inmersos en el mundo económico de los negocios y recaudaciones, cambios y préstamos, se les acotaba sus campos de trabajo y con e.llos un número abundante de asociados y asalariados. Crece entonces, por lo que se refiere a Murcia, el número de conversiones, difícil de evaluar, pero que suponen una baja considerable de los componentes de la aljama y que alcanza su punto más alto en los primeros meses de 1411 (18). Pero tan sólo algunos nombres, los de aquellos que se presentaron ante los regidores y solicitaron ayuda económica por diversos motivos, pero siempre con la base de su conversión, son los que conocemos. La cifra no es alta y, por otra parte, las perspectivas que presenta la aljama murciana ya en la mayor edad de Juan II, permiten deducir que no debía ser número alto, si bien la aljama no alcanzaría ya el floreciente desarrollo, amplitud en su espacio urbano y densidad demográfica que tuvo en la década 1397-1407, pese a la considerable baja sufrida en los dos años anteriores a consecuencia de la peste (19).

Y la actitud del concejo de Murcia parece variar, ya no es la misma que en los años siguientes a 1391. Ahora se procura facilitar la adecuación de los conversos a la sociedad cristiana, se les concede ayudas o limosnas y se les atiende con preferencia en la contratación de servicios como menestrales singulares en oficios con escasa representación. Posibilidades que facilitan la conversión de algunos, que perciben camino de

(18) Moros, judios y conversos en la regencia de don Fernando de Antequera, CHE, XXIX, Buenos Aires, 1960, 60-97.

(19) Los judios murcianos en el reinado de Juan II de Castilla, Murcia, 1965. Murgetana, XXIV, 77-107. 
fácil acceso o de medrar rápidamente. Y los hay de todas clases. Son otras las perspectivas, otros los medios y otras las consecuencias.

\section{LOS CORREDORES}

El aumento de población urbana lleva consigo el incremento del comercio, tanto el más regular y cotidiano que tiende a mantener satisfactoriamente abastecida la ciudad, puesto que son ya muchos los vecinos y moradores que no trabajan en la tierra y necesitan proveerse en el mercado, del vendedor ambulante o en las plazas, como de aquellos artículos que no se producen o realizan en el territorio, bien sean telas de variadas clases y colores, bien especias, armas, pieles, piezas de orfebrería o joyería, vino cuando escasea el de la tierra o cualquier otro producto natural o fabricado. Surge entonces, intermediario del mercader, del productor o del abastecedor general al por mayor y del consumidor, del pueblo que compra y adquiere lo que les es necesario, la figura del corredor, especializado en la compraventa de determinados artículos, unos que se le entregan y otros que él procura proporcionar de lo que se le encarga, mediante un tanto por ciento del precio convenido, que es su corretaje, y que pagan por mitad comprador y vendedor.

En el reinado de Alfonso XI, al producirse un aumento considerable del comercio es cuando se legisla por el concejo las obligaciones y derechos de los corredores, forma de controlarlos y de poder intervenir siempre que lo considerara necesario, fijando precios y procurando que se realizara el servicio del modo más eficaz posible. Una de sus intervenciones fue la de disponer que los judíos que quisieran ser corredores tendrían previamente que renunciar a su fuero propio y someterse, en todo cuanto pudiera afectar al oficio de corredor, a las ordenanzas concejiles, ya que, amparándose en sus privilegios los judios rechazaban que los cristianos pudieran atestiguar contra ellos o ser juzgados por 
jueces cristianos y no por privativos, con lo que eludian las penas y castigos que debian sufrir por sus malfetrías.

Esta disposición de 1313 permitiría establecer una igualdad jurídica en cuanto a que los alcaldes extendían su acción tutelar por igual a todos los corredores; se hizo obligatorio también su previa presentación por los jurados, tener fiador, que solía ser persona conocida y de solvencia económica que se responsabilizaba de cualquier daño, fraude e incluso huida del corredor, así como prestar juramento ante los alcaldes de cumplir fielmente su oficio. En 1335 sólo podían ser corredores de Levante, aunque se mencionan y especifican entonces actividades de los corredores de cambios, ropas de cuello, heredamientos, bestias, fruta, paños, seda, cuero, etc. En 1375 cita Valdeón a tres de oreja o cambio, cuatro de ropa de cuello y siete de levante, con lo que el campo operativo de los judíos se ampliaba considerablemente. En cambio, en 1390, su participación había disminuido: cuatro de los cinco que había de Levante, uno de los seis de ropa de cuello y tres de los cinco de bestias.

Las persecuciones o prevenciones que a partir de este año se producen contra la grey hebraica ocasionan la deserción de muchos de los que hasta entonces habian sido buenos judíos, aunque nada sabemos de su número, así como el apartamiento o exclusión de otros. Pero en su mayor parte, los que pudieron, siguieron ejerciendo los mismos oficios que tenían antes de su conversión, por lo que regularmente dismiruye el número de judíos en este oficio, en el que no parece haber discriminación alguna y trabajan juntos cristianos y judios, si bien se reduce su participación en algunas especialidades. Mayor incidencia ocasionaría la predicación de San Vicente Ferrer y la promulgación de las restrictivas ordenanzas concejiles, a las que seguirian poco después las dictadas por los regentes de Juan II, puesto que se prohíbe su trabajo en muchos oficios o se limita su participación, como sucede en el de corredor, ya que no vuelven a mencionarse corredores judios aceptados por el concejo entre 1411 y 1413, precisamente por esta causa. 
En la relación de los judíos que ejercieron el oficio de corredor con autorización municipal en estos años se aprecian unas oscilaciones que no tienen una explicación precisa, aunque a veces se observen aisladas omisiones, que en algunos casos son por entero circunstanciales, como es la de Yuçaf de Jaén, activo desde 1395 a 1410 y que falta en 1398, o caso semejante el de Lezar de Lunel. Si cabe señalar que sólo hay una mujer y no se especifica su especialidad, en tanto que son siete de ropa de cuello y dieciséis de oreja, los más apropiados a sus características, normales ocupaciones de su trabajo y forma de realizarlo, más aún en el pueblo bajo, con el que preferentemente ejercían estas actividades, pues la mayor parte de estos artículos eran usados y pocos de creación. Porque desde los días de Alfonso $\mathrm{X}$ y tras largo período en los de Alfonso XI, el lujo en el vestir provoca la repulsa, prohibición y coto de la legislación suntuaria que se dispone por reyes y Cortes. $\mathrm{Y}$ el oficio de corredor es precisamente con Alfonso XI cuando se regulariza y la institución adquiere carácter oficial y adecuado control (20). Y lo es no sólo por el carácter y actitud de un monarca enérgico y legislador, sino como consecuencia de una mayor actividad económica y de la compraventa urbana, en la que, síntoma de los tiempos, contrasta el excesivo uso de telas costosas en el vestir de la oligarquía dirigente y la deplorable economía del resto de la población en donde interviene el corredor, especialmente en la compraventa de ropa, frecuentemente usada, pero que no por eso deja de ser apetecida y costosa, pues no está al alcance de todos. A estos corredores se agrega uno de fincas y otro de Aledo, polifacético, que todo lo arreglaba

En la venta de ropa el corredor ocultaba el nombre de su propietario, unas veces porque siendo de gente acomodada no querian que se supiese que la daban a vender, pero por lo general procedía de pobres vergonzantes. $\mathrm{Y}$ algunos corredores se aprovechaban de la posibilidad que se les ofrecía de ocultar estas ventas a los arrendadores de las alcabalas y beneficiase indebidamente. Lo que motivó que los arrendadores

(20) TORRES FONTES, J.: Los corredores del comercio murciano en el reinado de Alfonso XI, M.M.M., IV, 1978, 239-262. 


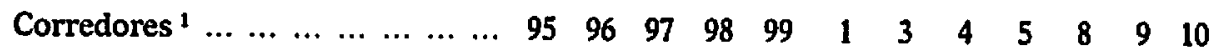
$\begin{array}{llllllllllllllll}\text { Abrahem el Ballestero } & \ldots & \ldots & \ldots & \ldots & \mathbf{R} & \mathbf{R} & \mathbf{R} & \mathbf{R} & \mathbf{R} & & \mathbf{R} & \mathbf{R} & \mathbf{R}\end{array}$ Abrahem Aben Aldel

$\mathbf{R}$

o 0

Abrahem Amen Braçera

Abrahem Resta ... ... ... ... ... ... ...

Abrahem Azarayas $\ldots \ldots \ldots \ldots$

$\begin{array}{llllllllll}\text { Aljofar } & \ldots & \ldots & \ldots & \ldots & \ldots & \ldots & \ldots & \ldots & \ldots\end{array}$

$\mathbf{R}$

$\mathbf{R}$

$\begin{array}{lllllllllll}\text { Benvenieste } & \ldots & \ldots & \ldots & \ldots & \ldots & \ldots & \ldots & \ldots & & 0\end{array}$

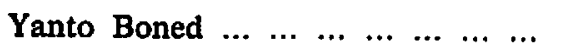

Yuçaf Abenaça $\ldots \ldots \ldots \ldots \ldots$

Yuçaf Aben Çaydon $\ldots \ldots \ldots \ldots \ldots$

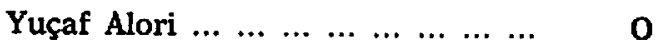

$\begin{array}{lllllll}0 & 0 & 0 & 0 & 0 & 0\end{array}$

$\begin{array}{llllllllllllllll}0 & 0 & 0 & 0 & 0 & 0 & 0 & 0 & 0\end{array}$

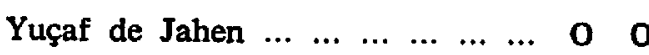

$\begin{array}{lllllll}0 & 0 & 0 & 0 & 0 & 0\end{array}$

Yuçaf de Usal ......................

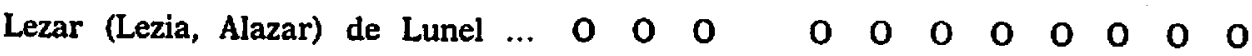

$\begin{array}{lllllll}\text { Maymon Cascorro }^{2} & \ldots & \ldots & \ldots & \ldots & \ldots & \ldots \\ \end{array}$

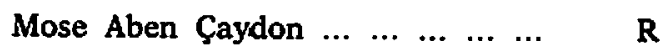

Merdofay $\ldots \ldots \ldots \ldots \ldots \ldots$

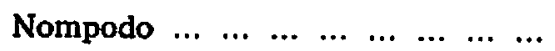

Salomon Aben Pica $\ldots \ldots \ldots \ldots, \ldots$

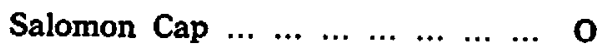

o

$\mathbf{R}$

$\begin{array}{llllllll}\mathbf{R} & \mathbf{R} & \mathbf{R} & \mathbf{R} & \mathbf{R} & & \mathbf{R}\end{array}$

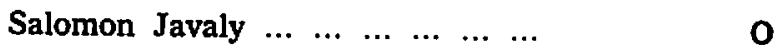

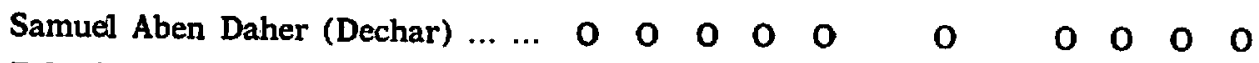

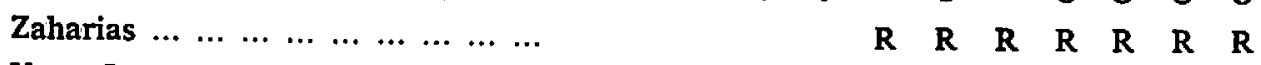

Yçag Caparel

Yçag Modur

\begin{tabular}{llllllllllllll} 
& \multicolumn{1}{c|}{$F$} \\
\hline 6 & 10 & 5 & 6 & 8 & 8 & 13 & 10 & 8 & 8 & 8 & 9
\end{tabular}

1 Oreja, Ropa, Corredora, Fincas. de Aledo». 
exigieran que se les entregara relación escrita de los nombres de sus propietarios para evitar que se les encubriera cualquier transación. Al pasar de un extremo al otro, la disposición perjudicaba a los corredores, porque eran muchos los que se negaban a entregarles objetos o ropas a vender con tal de que no se supiera su nombre. Lo que solucionó el concejo mediando con Zag Abudaran y sus «compañones», arrendadores de las alcabalas y zurundaja, ofreciendo como solución que alos jodios corredores cada que algund peño les fuera dado, que lo escrivan en poder del dicho arrendador, e que le non digan cuya es» (21).

\section{FIELES DE RENTAS}

Entre la adjudicación, nombramiento y comienzo de gestión de los arrendadores y recaudadores de las rentas reales transcurría un período de tiempo más o menos prolongado, en que regularmente no se habrían cobrado las rentas de alcabalas, diezmos y almojarifazgo o se hubiera efectuado con retraso con la consiguiente pérdida, que podía suponer a veces cantidades importantes y aumento de las dificultades para conocer y recaudar, si no se hubieran adoptado medidas previsoras. Con objeto de que la recaudación no sufriera tal menoscabo ni entorpecimiento y salvar este período de tiempo entre el comienzo del año y el de la presentación de la carta real concesionaria del arrendamiento y la actividad de los recaudadores, el concejo a propuesta de los jurados y aprobación de los alcaldes, designaba, previo particular concurso, los fieles que se encargaban de la cobranza de las alcabalas, diezmos y almojarifazgos "porque recauden en fieldat fasta que vengan los arrendadores de aquellas e les den cuenta de lo que asi recabdaren e cogeren". No faltaba tampoco el nombramiento de escribanos que relacionaban las cantidades recaudadas, para justificar posteriormente las cuentas. Todos ellos, fieles y quienes escribian -que no eran escribanos de oficio- tenían que presentar ante el concejo a personas abonadas que les afianzaran de su buen hacer y se responsabilizaran de cualquier fallo, fraude o engaño.

(21) A. Capitulares, 8-IX-1403. 
No tenemos constancia documental de todo este periodo (1390-1415), tanto porque faltan algunos volúmenes de las actas capitulares de años intermedios, como es, por ejemplo, el de 1400, como porque los escribanos concejiles, aunque dejando en blanco previsoramente el lugar correspondiente - fines del año natural - para su posterior relleno, nunca llegaron a copiar la relación de los fieles encargados de la recaudación de las rentas reales. Este es el caso, entre otros, de 1403, en que sólo se indica a David Aventuriel de Uclés en la renta del carnaje, y a continuación folio y medio en blanco.

La designación de los fieles por los jurados se efectuaba con adjudicación parcial o total de cada renta, y en ello parece haber acuerdo previo entre los aspirantes a hacerse cargo de su fieldad. El ejemplo de cómo se distribuyen las alcabalas del año 1395 manifiesta con claridad la forma de cómo se adjudicaba:

Carnaje: David Aventuriel, 1/6; Pedro de Cuenca, Pedro Oller y Yuçaf Aventuriel de Chinchilla, 1/3; Zag Aventuriel (h. de Salomón), 1/6; David Aventuriel de Uclés, $1 / 6$.

Traperia: Samuel Abenaex.

Aduana mayor: David Aventuriel de Uclés, 2/3; Mosé Cohen, el viejo, 1/6; Abrahem Aben Sabat, 1/6.

Pan y vino: Jacob Aventuriel (h. de Zag el Calvo), 1/3; David Aventuriel (h. de Salomón), 1/3; Samuel Arrodin, 1/3.

Cerundaja: Pedro Sánchez de Montoro y Yuçaf Axaques, 2/3; Abrahem Alorí, 1/3.

Judería: Zag el Barçeloni.

Zapateria: García Sánchez de Montoro, 1/2; Mayr Fidauque, 1/2.

Moreria: Yahuda Aben Aladar, 2/3; Mosé Aventuriel (h. de Yuçaf), $1 / 3$. 
La estadística permite apreciar el elevado número de judíos que participan en 1395 y aunque dos años más tarde decrece, es para experimentar seguidamente una continuada subida en los años posteriores hasta 1405, desde el cual se produce de nuevo el descenso (22) hasta la total eliminación de los judios como fieles en la recaudación de alcabalas, diezmos y almojarifazgo en 1409:

\begin{tabular}{ccccc} 
Año & Cristianos & Judios & Conversos & Moros \\
\hline 1395 & 18,18 & 81,81 & & \\
1397 & 32,00 & 64,00 & 4,00 & \\
1398 & 25,71 & 65,71 & 2,85 & 5,71 \\
1399 & 27,58 & 65,47 & & 6,89 \\
1402 & 23,52 & 70,58 & & 5,88 \\
1405 & 21,42 & 78,57 & & \\
1406 & 38,88 & 58,33 & 2,77 & \\
1407 & 44,44 & 51,85 & & 3,70 \\
1408 & 53,12 & 46,81 & & \\
1409 & 100,00 & 0,00 & &
\end{tabular}

Cincuenta y seis nombres distintos (23), muchos de los cuales se mantienen casi ininterrumpidamente en los diez años estudiados, muestran la activa participación de los representantes judios, entre los cuales es normal la intervención de los miembros de una misma familia, cada vez más amplia, en todas las rentas, como sucede con los catorce Avenutriel que vemos alternando en casi todas ellas. En lo que se refiere

(22) El descenso judio y aumento cristiano a partir de 1406 motivado por el cambio que se precisa en muchos aspectos de la vida urbana, permite deducir que muchos de los cristianos que comienzan a participar como fieles y cuyo número crece en los años siguientes, eran conversos, pero por sus nombres no re. sultan identificables.

(23) La diversidad de formas con que se escriben los nombres judíos por un escribano en un mismo año, a veces con diferencia de días, obliga a agruparlos en una sola denominación, la más usual, que no significa que sea la más co. rrecta. Abrahem Aben Aladar, el mozo; Abrahem Aben Aladar, el viejo; Abrahem Aben Arroyo; Abrahem Aben Sabat; Abrahem Alari; Abrahem Almateçy; Abrahem Axaques; Abrahem Cohen, el mozo; Abrahem Mudur; Astruch, maestro; David Avendaño; David Aventuriel (h. de Salomón); David Aventuriel de Uclés; Haym Abenatar; Haym Mudur; Jacobo Aventuriel (h. de Yçag el Calvo); Jacob Ropapa; Luengo, físíco; Mayr Abenaex; Mayr Avendaño; Mayr Fidauque; Mosé Abeniahay- 
al número de fieles y distribución de las rentas no son siempre los mismos, pues si algunos se repiten, otros, en cambio, se les menciona indistintamente en unas y otras, sin que haya una forma regular de acomodación o distribución. En ocasiones las rentas de las alcabalas se acumulan: carpintería, cerundaja, zapatería, Almudí, etc., y en otras se realizan por separado e incluso las hay que sólo aparecen por una sola vez, como el poblado de Santaren, lugar de los Arróniz.

Fieles judios en las rentas de alcabalas y almojarifazgo

139513971398139914021405140614071408

Aduana mayor, almojarifazgo ........

Aduana moros, almojarifazgo .........

Aduana nueva, almojarifazgo .........

Aduana moros, alcabala $\ldots \ldots \ldots \ldots$

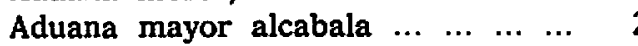

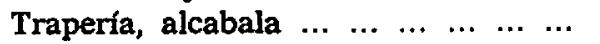

Pan y vino, alcabala $\ldots \ldots \ldots \ldots \ldots \ldots$

Carnaje, alcabala $\ldots \ldots \ldots \ldots \ldots \ldots$

Judería, alcabala $\ldots \ldots \ldots \ldots \ldots \ldots$

Zapatería, alcabala ..................

Zerundaja, alcabala $\ldots \ldots \ldots \ldots \ldots \ldots$

Carpintería, alcabala ... ... $\ldots \ldots \ldots \ldots$

Almudi, alcabala $\ldots \ldots \ldots \ldots \ldots \ldots$

Santaren, alcabala $\ldots \ldots \ldots \ldots \ldots \ldots$

$\begin{array}{lllllllllll}\text { Judería } & \ldots & \ldots & \ldots & \ldots & \ldots & \ldots & \ldots & \ldots & \ldots & \ldots\end{array}$

Total $\ldots \ldots \ldots \ldots \ldots \ldots$

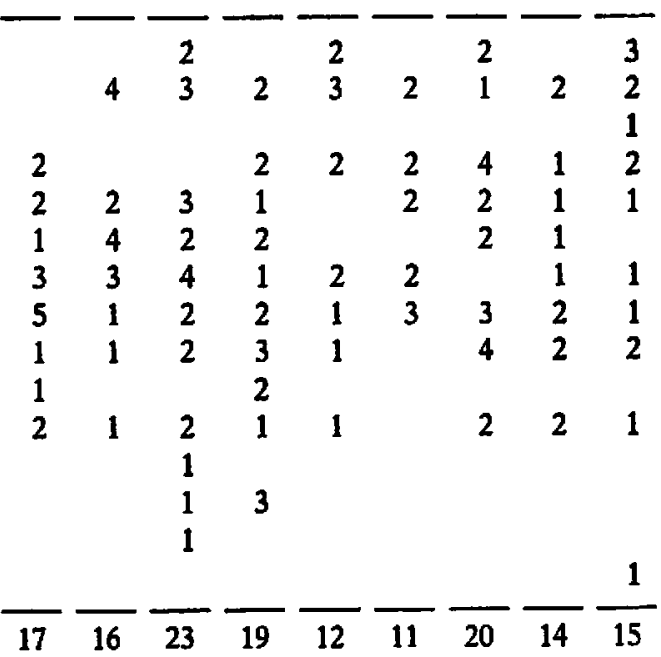

A estos cincuenta y seis fieles que se responsabilizan de la recaudación de las rentas reales hay que añadir quienes como subordinados

met; Mosé Abeniaex; Mosé Aventuriel el Calvo; Mosé Aventuriel (h. del Calvo); Mosé Aventuriel (h. de Yçag el Rojo); Mosé Aventuriel (h. de Salomón); Mosé Aventuriel (h. de Yucef); Mosé Axaques; Mosé Cohen, el mozo; Mosé Cohen, el Viejo; Mosé Cohen Abenbay; Mosé Cohen de Briviesca; Mosé Cohen Segilmeçu; Mosé Ximuel (Comiel); Salomón Aventuriel (h. de Yçag el Rojo); Samuel Abenaex; Samuel Alsax: Samuel Azaban; Samuel Arrodin; Vidal Bonjua; Yahuda Aben Aladar; Yahuda Cohen; Yçag el Barçeloni; Yçag Abulhaçan; Yçag Aventuriel, el Rojo; Yçag Aventuriel (h. de Mosé); Yçag Aventuriel de Chinchilla; Yçag Aventuriel (h. de Salomón); Yuçef Aventuriel de Chinchilla; Yuçef Axagues; Yuçef Mudur, el viejo; Zuleyman Alahaçan; Zuleyman Aben Arroyo; Zuleyman Abenaça. 
suyos, gente de su propia raza, trabajaba a sus órdenes, en número no cuantificado. También cabe deducir que gran parte de ellos seguirian en su labor cuando llegaran los recaudadores, con menor responsabilidad y menores ganancias, pero útiles por su conocimiento y experiencia, lo que facilitaría la continuidad en la normal recaudación de las rentas reales. Pero continuidad no siempre segura, porque a veces su labor dejaba de desear y de ser apetecida y esperada. Por lo que no extraña que cuando el 23 de julio de 1392 tomaba posesión del alguacilazgo mayor de la ciudad Juan Sánchez Manuel, entre otras cosas se hiciera cargo de dieciocho personas que se hallaban presas en la cárcel concejil, doce de los cuales eran judíos, todos bien conocidos por su actividad como fieles en la recaudación de las rentas (24), por débitos a Sancho Rodriguez Pagán. Tal número superaba las posibilidades de habitación y vigilancia, por lo que el alguacil requirió a los alcaldes que libraran sus sentencias con prontitud y ulos que mereçen la muerte que ge las den e los que mereçen ser quitos, que los den por quitos... los quales dixeron que eran prestos de lo fazer».

Las quejas contra las malversaciones y fraudes o falta de pago de los fieles se hizo tan pública y patente que los acostumbrados arrendadores y recaudadores dejaron de participar porque alos fieles que en ellas se ponen non les fazen buena verdat e aun que de los maravedis que de las dichas fialdades reçiben que non ge los pagan como deven". Situación que motivó un cambio general en la designación de fieles por decisión real. El monarca dispuso que se pusiera en almoneda las rentas con objeto de adjudicarlas a los que mayores precios ofrecieran y fueran ellos los que pudieran «coger e recabdar en fialdat» hasta que se arrendaran. Adjudicación previa fianza, y para mayor control y seguridad, el monarca designaba a Lope González de Toledo, su escribano y Antón Sánchez de Córdoba, su recaudador mayor del obispado de Cartagena, para que inspeccionaran y dirigieran estas concesiones e incluso autori-

(24) Mayr Avendaño; Mosé Cohen, el viejo; Mosé Cohen de Briviesca; Yçag Aventuriel (h. de Salomón); David Áventuriel (h. de Yuçef); Yuçef Mudur, el mozo; Salomón Abenlup; Mosé Alorí; Mosé Aventuriel (nieto de Mayr); Jacob Aventuriel (h. de Yçag). 
zados para designar personas de su confianza como fieles de aquellas rentas que no fueran ofertadas o adjudicadas (25).

La actividad de los judíos como fieles en la recaudación de rentas tiene también su fin en 1408. La presión antijudaica se impone en el plano económico. Recordando disposiciones de las Partidas, los regentes de Juan II redactan su Ordenamiento de 25 de octubre de 1408 por el cual, tras exponer que la intervención de los judios en el arrendamiento y recaudación de las rentas reales o como fieles, portazgueros y cogedores les proporcianaba poder sobre los cristianos y posibilidad de ocasionarles agravios y perjuicios, prohibían su participación en todas ellas. Y la prohibición se extendía igualmente a su intervención indirecta por segunda o tercera persona, o simplemente como fiadores, especificando que siendo probada su participación, sería penado con multa de cuantía igual a la renta en que interviniera y cincuenta azotes, siendo bastante el testimonio de dos judíos, judio y cristiano, dos cristianos o por confesión propia; trato semejante tendría el cristiano que tuviera asociado al judío, con testimonio de dos cristianos o confesión propia, lo que supondría igual multa y un año de servicio de armas en un cas. tillo fronterizo. Al mismo tiempo se incitaba al «pueblo» a denunciar iales casos, con premio de una tercera parte de la multa que se impusiera. Sólo se hace una excepción, el que la disposición no entraría en vigor hasta el año 1409 con objeto de no ocasionar perjuicios a nadie (26).

\section{LOS MENESTRALES}

La variedad del vestido medieval y el uso de telas y paños de muy distinta calidad y colores, iba a tener amplia repercusión en el reino de Murcia en la segunda década del siglo xIV, cuando comienza un gradual despegue de la profunda depresión económica y demográfica sufrida

(25) A.M.M. Cart. 1391-1412, fols. 71-72.

(26) Apéndice, doc. IV. 
durante cincuenta años, en los que diversos intentos de variado alcance no tuvieron fuerza y continuidad para superarla. $Y$ el cambio, incremento, decidida atención concejil, innovaciones, ordenanzas, aumento de las importaciones y otra serie de factores que afectan al vivir general de sus habitantes comienza a hacerse sentir ya de forma muy apreciable en los primeros años de la mayor edad de Alfonso XI. Una de sus manifestaciones más precisas se ofrece en la confección propia de tejidos, en los que en principio no se alcanza una perfección y calidad técnica capaz de competir o sustituir a los que se importaban, pero sí para abastecer el mercado ciudadano de las telas más necesarias en el uso doméstico o personal, y cabe deducir que también se comienza la confección del vestido del ocio. Con ello se crea una industria artesanal que proporciona trabajo urbano, permite la especialización y con el aumento de la producción se logra la reserva legal de la mitad de la lana que se obtenía en los rebaños trashumantes que acudían a invernar en territorio murciano; lo que supone comienzo también en la restricción de importaciones de las regiones vecinas por un lado y mayor actividad laboral, con gradual mejora en cuanto a calidad de tejidos y variedad de colores, por otro, más la creación de talleres auxiliares y dependientes de los más importantes.

Pero la producción propia no hizo disminuir la importación de telas valiosas y de costosos adornos con que se confeccionaban los vestidos, artículos con los que comerciaban los grandes mercaderes genovests. Para frenar excesos el concejo intervino con la redacción de amplias relaciones de telas y adornos, con el propósito de poner coto a precios y salarios, pero también con el de delimitar y fijar el uso de diversas prendas y de sus costosas guarniciones, con especial dedicación a las femeninas, pues entonces, como en cualquier otro tiempo, el vestir bien era una de las tres ansiadas metas que anhela conseguir la mujer que vive en la ciudad (27). Variedad y a veces orgía de colores y la suma de todo ello en un mismo vestido; los adornos de valiosas joyas y pieles

(27) TORRES FONTES: Ordenanza suntuaria murciana en el reinado de Alfonso XI, M.M.M. VI, Murcia, 1980, 99.132.

88 
con que se enriquecen toda clase de vestidos y la introducción de novedades, cambio de moda, más el competitivo deseo de originalidad y de distinción, ocasiona no sólo gasto, sino tiempo y sobre todo gran número de personas especializadas en el trabajo que supone la confección de tejidos, tintado y hechura de vestidos. $Y$ la consecuencia inmediata es el aumento de alfayates, dedicados indistintamente a vestir a hombres y mujeres.

Trabajo que exige habilidad, paciencia, gusto, delicadeza y largo aprendizaje y que pronto sería profesión apetecida y bien remunerada, por lo que en ella participan cristianos y judios, con ventaja para éstos por su mayor capacidad para tales labores y especialización al trasmitirse familiarmente sus conocimientos y experiencias. De aquí el que gradualmente fueran monopolizando el trabajo y los alfayates judíos sustituyeran a los cristianos en el corte y confección de toda clase de vestidos para los vecinos de la ciudad (28).

Pero en ocasiones el normal desenvolvimiento de la vida sufría atas$\cos$ y ocurrían hechos que al producir perjuicios, sus consecuencias repercutían sobre unos y otros. Cuando, por distintas causas, los judios incurrian en algún delito o se hallaban imposibilitados para pagar los impuestos o tributos que se exigían en la ciudad, o llevados por el simple propósito de apropiarse de lo que no era suyo, siendo bienes de fácil ocultación o transporte, sigilosamente marchaban a la gobernación de Orihuela, lo que les ponía a salvo de la acción judicial castellana. La repetición de tales perjuicios obligó al concejo a adoptar medidas adecuadas para evitarlos. $Y$ especialmente en lo que afectaba a los alfayates judíos, pues se llevaban las telas que se les entregaban para su

(28) Pero no exclusivo ni total, asi como en ocasiones su trabajo dejaba descontentos a sus clientes. El acuerdo concejil de 26 de octubre de 1409 relaciona alfayates judíos $\mathrm{y}$ cristianos y acusa a algunos de ellos de sisadores: aalfayates e costureros que fazen algunas cosas en sus ofiçios que eran en gran daño de la dicha çibdat ... espeçialmente en los tajos de las dichas ropas, que es fama que toman del paño que... les dan a cortar e non ponen todo el paño que les dan ... se pese ante e despues... qualquier alfayate asi cristiano como judio que non los den sin pesar. 
corte y confección que no era posible recuperar, y al mismo tiempo seguían siendo necesarios sus servicios, por lo que en la reunión concejil del día 2 de diciembre de 1374 se adoptó el acuerdo de que los judíos alfayates para poder seguir trabajando entre cristianos tendrían que presentar previamente fiadores ante los jurados. $Y$ seguidamente se pregonó públicamente el acuerdo: «Por mandado del conçejo que ningund judio alfayate que non sea osado de tomar nin reçebir a tajar nin a coser de christianos algunas ropas nin paños algunos fasta que ayan dado fiadores en poder de los jurados que cunpliran de derecho a todos aquellos que querella ovieren dellos por razon de las ropas e paños que las gentes les dieren a coser, so pena de seysçientos maravedis por cada vez".

A esta primera fase de exigir a cada alfayate que personalmente presentaran fiador ante los jurados, pronto hubo de introducirse modificaciones, pues la dificultad que entrañaba el que todos los judíos pudieran encontrar persona adecuada y abonada que quisiera prestarse a ello, se añadía su número. Por este motivo el concejo de acuerdo con la aljama buscó un medio más propicio y fue el que la aljama auto. rizara con su firma y acuerdo la relación nominal de los menestrales que ella aseguraba, por lo que colectivamente se responsabilizaba de cualquier daño que alguno de los judios asegurados pudiera producir.

En el período 1398-1413, en los siete años de que queda relación, el número de menestrales judíos afianzados por su aljama es el de trescientos cincuenta y uno, pero al repetirse los mismos nombres dos o más años, la cifra se reduce a ciento veinticuatro, de los cuales su mayor parte son alfayates, pues el número de setenta y nueve con esta denominación, es ampliable, ya que hay doce menestrales de los que no' consta su oficio y cabe deducir que algunos de ellos eran también alfayates.

No resulta sorprendente este cuantioso número de alfayates judíos que sirven y trabajan para los cristianos por las razones antes indicadas: 
variedad de tejidos y colores en hombres y mujeres, así como la habilidad y esfuerzo que requerían los vestidos del ocio. Alfayates que, individualmente tendrían entidad propia, pues trabajaban por separado unos de otros, lo que supone un «taller», en que sin duda colaborarian otras personas de su propia familia.

La seguridad que proporcionaba esta responsabilidad de la aljama, hizo que la relación de personas afianzadas se extendiera a otros menestrales judios que trabajaban para los cristianos, en que se cuentan en estos años a quince tejedores, cinco tintoreros y otros tantos plateros, más seis juboneros, cuatro banoveros, una torcedora, un sazonador y una corredera.

No aparece o no encontramos la causa que motiva una fluctuación anual bastante considerable en el número de alfayates asegurados por la aljama, como es la que supone pasar de 44 en 1398 a 62 en el año siguiente, o los treinta y dos a que baja en 1403. No se debe a omisión del escribano que involuntariamente dejara de incluirlos al realizar su inserción en las actas capitulares, lo que sí podria ser en el caso de quienes se repiten año tras año y queda uno sin mencionar, como ocurre con Abraham el Talaví o Haron Alulayes, pero nunca en número tan amplio (29).

\section{POBLACION}

Resulta difícil, cuando no aventurado, intentar cifrar aunque sóto sea de modo aproximado la población judía en la ciudad de Murcia

(29) Como más arriba indicamos, la diversidad de escribanos que redactan las actas capitulares y la dificultad que para ellos representaba transcribir fielmente el nombre, apellido e incluso apelativo de la relación de los judios asegu. rados por su aljama, que se les entregaba por escrito o expresaba a viva voz, entorpece en ocasiones su identificación. De aquí que en el cuadro (Apéndice, doc. 1) se ordenen alfabéticamente por nombres, en lo posible unificados y aportando cuando nos ha parecido adecuado, las distintas versiones de sus nombres y apellidos. De igual forma la relación de nombres se realiza manteniendo el más usual en cada caso: Abrahem, Mose, etc. 
entre 1391 a 1415. Contamos con un excelente estudio sobre la inmigra. ción en Murcia en un amplio periodo, 1370-1420, en que precisamente se incluyen los veinticinco años que como máximo abarcamos (30) y su autor nos dice que en los cincuenta años estudiados "L'Aljama de Murcic ne reçoit qu'un faible contingent d'immigrants, una quarentaine». Ell número no puede ser más escaso y de los que llegan identifica a dos procedentes de Málaga (1392, 1405), siendo los restantes de la Corona de Aragón y de ellos la mitad aproximadamente de Orihuela; y "passé 1391, les arrivées s'echelonnent a raison d'une ou deux par an, juscu'en 1411. (31). Su aportación la realiza por los datos que obtiene de las actas capitulares del concejo murciano, si bien faltan algunas de ellas y, sobre todo, la del año 1391.

Pudo incrementarse de modo abundante la aljama murciana en 1391 y en avalancha, sin previo aviso, presentarse en ella un gran número de judios oriolanos. Si, como parece, a causa de las alteraciones que se suceden en el reino de Valencia en 1391, a la población judía de la gobernación de Orihuela sólo le quedó un doble camino a elegir: la disyuntiva de conversión o huida. Deducimos que fueron mayores las conversiones, pero sin duda hubo también muchos que decidieron emigrar y, conociendo la decidida actitud protectora de las autoridades murcianas, buscaron refugio en su ciudad, que debió ser acrecentar, aunque fuera momentáneamente, el número de quienes habitaban en el recinto de la juderia.

Pero a este incremento, que no tiene continuidad en los años siguientes, se iba a contraponer una baja considerable cinco años más tarde. Es cuando en 1395-96 la ciudad de Murcia sufre las catastróficas consecuencias de una epidemia de peste que ocasiona 6.088 muertos, de los

(30) MENJot, Denis: L'Immigration d Murcie et dans son territoire sous les premiers Trastamares (1370-1420 environ), aRevue d'Histoire Economique et Social, 1975, vol. núm. 2-3, pág. 245.

(31) Faltan diversas actas capitulares, por lo cual la relación siempre será incompleta. Por otra parte, cabe indicar la llegada de Samuel Bonafis, en 1399, procedente de Barcelona, y la de un converso, Paulo de Bonafé, que en 1410 llega a Murcia desde Zaragoza. 
cuales 450 eran judios, lo que supone un 7,4 por 100; cifra muy importante (32) y que sin duda supera por mucho cuanto hubieran podido proporcionar los huidos de la gobernación de Orihuela en los años an. teriores.

Que la aljama era populosa, aun después de las pérdidas de 1395-96, se pone de manifiesto en que tres años más tarde, en 1398 y 1399, son 52 y 62 los menestrales judíos afianzados por su aljama; a ellos se sñaden en los mismos años 23 y 19 fieles de rentas, más 6 y 8 corre. dores que reciben autorizacion concejil para trabajar en sus respectivos oficios entre cristianos; la suma por estos tres conceptos es de 81 y 79 individuos. Cifra importante, pero no definitiva, porque a ella habría que agregar otros menestrales que trabajaban en el mismo oficio, pero que la aljama no incluia en sus relaciones por la inseguridad de su proceder, mala calidad de su trabajo o por cualquier otra causa (33). De igual forma habría que contar con aquellos cuya labor es entre cristianos, pero que no necesitan licencia del concejo para su actividad, como eran los auxiliares y servidores de los fieles que cobraban las rentas en los comienzos de cada año hasta la llegada de los recaudadores y que, posiblemente, parte de ellos continuaran en el mismo trabajo el resto del año. Tal, igualmente, los físicos y cirujanos, con o sin el acuerdo favorable de los regidores para el ejercicio y reconocimiento de su profesión, ya que su asistencia era tan necesaria que para ellos no tenía mucho valor las prohibiciones o restricciones, y de los que conocemos los nombres de una veintena en estos años (34).

(32) TORRES FonTES: Tres epidemias de peste en Murcia en el siglo XIV, Universidad de Murcia, "Anales de Medicinas, 1, 1977, pág. 160.

(33) Tal los sazonadores Savaya (1403) y Abrahem Coauenyuid (1403 y 1405).

(34) David Damasco (1409); David Abenacox, que cobraba también por romancear las cartas moriscas del reino de Granada o de los alcaides de las aljamas de señorio y por escribir para Granada, lo que hizo durante más de veintitrés años (1408); Mayr Axaques (1406); Yuçaf Axaques, cirujano (1407); maestre Jacob (1406); Içag Ábenbayn, hijo de maestro Jacobo, físico (1399); Mayr Alguadix, físico (1395); Mayr Abenaaño, cirujano (1395, 1407); y su hijo Mose, cirujano (1415); Abrahem Alatar, físico (1395): Yuçef Banohaymy, físico (1396). Y con anterioridad, aunque algunos se mantienen en estos años: Vidal y Abrahem Abenbahi; Haym e Içag Abenaex; Mose Aventuriel, cirujano; Yçag Mudur (1390); Yuçef Abenalazar; Mose Baruque, etc. 
$\mathrm{Y}$ en tercer lugar aquellos cuya labor no se realiza directamente entre cristianos en estas cuatro ocupaciones $y$, por tanto, su contacto con la población castellana no era frecuente. Gente que ejerce su oficio dentro y fuera de la judería, pues las actas capitulares mencionan otros muchos judios que no se incluyen en las citadas relaciones, como era el carnicero Aben Celva, el cedacero Alegrías, el especiero-boticario Cohen, así como los innominados panaderos, zapateros y cuantos en actividades muy diversas eran o se hacían necesarios para el normal desenvolvimiento de la vida comunitaria de la aljama, aprovechando ocasionalmente por lus cristianos (35).

En su estudio sobre Los judios de Castilla y la revolución Trastámara, Valdeón (36) conjugando datos de las actas capitulares murcianas y las exigencias tributarias que se imponen a la aljama, de 25.000 maravedís, calcula el número de hebreos residentes en Murcia hacia 1375 en «unos 2.000 ". Por su parte, Roselló (37), al tratar de la judería murcianá en el período medieval y teniendo en cuenta la proporcionalidad de los judios fallecidos a consecuencia de la epidemia de peste en 1396 respecto al total de cristianos y moros también muertos por igual causa, entiende que «la población judia en uno de sus mejores momentos agruparia unos 1.150 individuos». Recientemente María Llanos Martínez Carrillo rebaja la cifra de población judía de forma radical. Aceptando «la propnrción de 7,4 de la población murciano-judía calculada por Roselló, en 1401 la judería tendría unos 700 habitantes, que en 1408 podrían ser unos 900 , como cifras máximas probables». Y a conclusiones semejantes llega la misma autora por los datos que obtiene en la contribución de los judios el año 1407, con 546 maravedís para el arreglo de la muralla, con aportación variable de 6, 4 y 2 maravedís por cabeza de familia; lo que supone por término medio el que pudo haber unas 180 familias

(35) La lista de los oficios que desempeñaban judíos y que se especifican en las ordenaciones reales de 1412 , a los que se les prohíbe su trabajo o comercio con cristianos, es también aplicable a la judería murciana.

(36) Valladolid, 1968, pág. 57.

(37) ROSELLO VERGER Y CANo, Gabriel: Evolución urbana de Murcia, Murcia, 1975, pág. 58. 
y unos 900 habitantes en todo el barrio. Y, por último, después de las conversiones de los años 1411 y 1412 la judería quedaría reducida a a poco más de 600 habitantes (38).

Contamos con otros datos numéricos muy alejados de estas fechas, pero aproximadamente equidistantes por uno y otro lado. En el Padrón de Huete, de 1291, corresponde al reino de Murcia el pago de 22.414 maravedís del total de dos millones y medio que abonaban los judíos cie Castilla por capitación, lo que supone un 0,89 por 100 . Por otra parte, de los 450.000 maravedís del Repartimiento del servicio y medio servicio que realiza Jacobo Aben Núñez el año 1474, a la aljama de Murcia se le asignan 8.500, más 200 a la de Mula, lo que representa el 1,93 por 100 , y si el obispado de Cartagena es entonces el que tiene menor número de juderías, en cambio, la ciudad de Murcia ocupa el cuarto puesto en el orden de las aljamas más populosas, lo que evidencia la concentración de los judíos en la capital del reino, acorde igualmente con la situación política y económica del adelantamiento, de sus centros de población y de las vicisitudes de sus aljamas (39).

De todo lo cual podemos, por nuestra parte, concretar la continuidad de una densa población, que, al contrario de lo que regularmente sucede en otras partes, se incrementa en 1391. Con los datos con que contamos, y siempre por la vía aproximativa que puede obtenerse de ellos, pero también de lo que cabe deducir por el desarrollo de los acontecimientos, de lo que fue la vida normal, de cuanto representa la mentalidad de sus gentes y de las decisiones concejiles, por nuestra parte podríamos cifrarla en número superior a 1.500 personas entre $1391 \mathrm{y}$ 1395; a lo que sigue la drástica baja de cuatrocientas cincuenta personas en 1396 y que después disminuye lentamente, aunque con oscilaciones, en los años siguientes. Frente a las cifras económicas hay que tener en cuenta la pobreza mayoritaria de los integrantes de la judería mur-

(38) MARTINEz CARRILlo: Revolución urbana y autoridad monárquica en Murcia durante la Baja Edad Media (1395-1420), Murcia, 1980, págs. 53 y 54.

(39) AMADOR DE LOS RIOS, J.: Historia social, politica y religiosa de los judios de España y Portugal, Edic. facsimilar, Madrid, 1973, págs. 302 y 1002. 
ciana. Una situación mísera — con excepciones- como para afectar la sensibilidad de un recaudador de contribuciones, tal como fue el caso de Juan Martínez de la Osa, quien por decisión propia, incluso enfrentándose con algunos regidores, suspendió el cobro del servicio del año 1393, a espera de la consulta que había hecho y que iba a llevar personalmente al rey, porque, según manifestaba, eran pobres y menesterosos.

En su conjunto cabe diferenciar cuatro fases: 1391, en que debió incrementarse considerablemente la aljama murciana con las aportaciones oriolanas, de aquí esa situación mísera en que se encontraba dos años más tarde; 1396, por cuanto le afecta la epidemia de peste y ocasiona una baja cuantiosa de su población; 1408, en que se hacen patentes medidas restrictivas, que afectan a su normal desenvolvimiento y rompen y frenan la continuidad y desarrollo de los años anteriores; y 1411-12, las predicaciones de San Vicente Ferrer y ordenamientos concejiles y reales, que producen numerosas conversiones y desaparición de distintas aljamas en el adelantamiento, en especial la de Lorca. Pero no mucho después, cuando acaba la regencia de la reina doña Catalina, la aljama murciana vuelve a adquirir un ritmo preciso que se mantiene de forma regular en los años que reina en Castilla Juan II y al frente del consejo real se mantiene don Alvaro de Luna. 


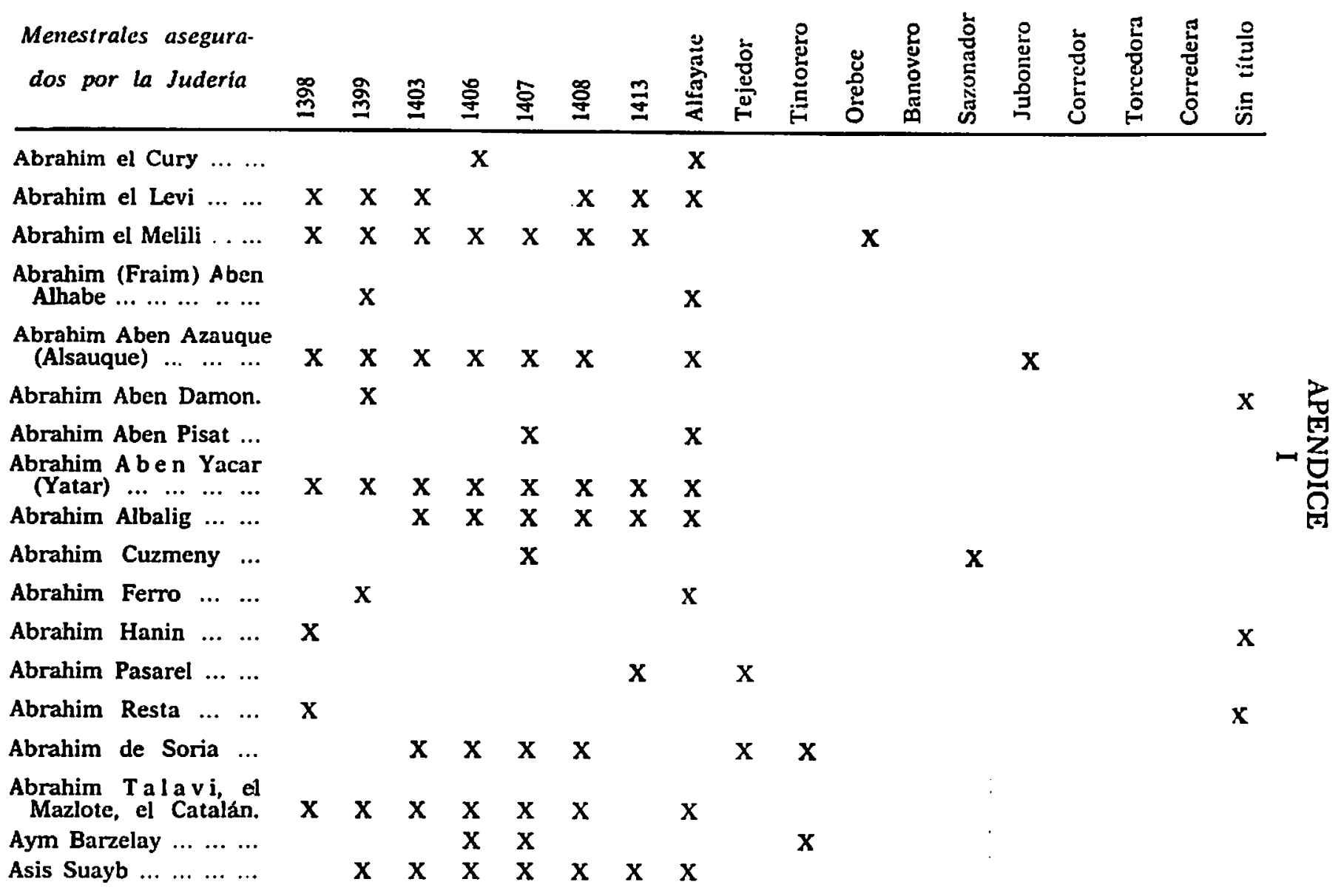




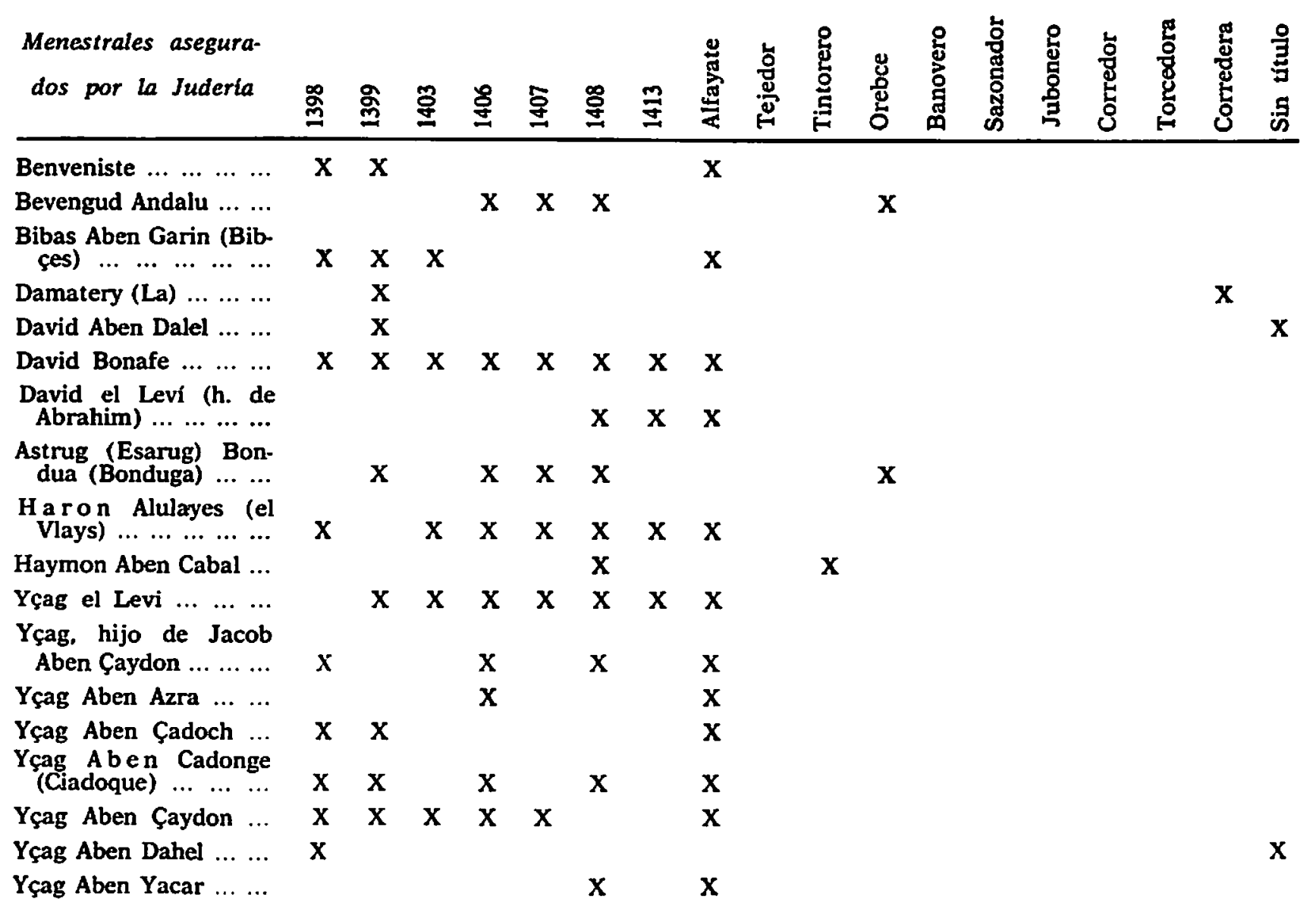




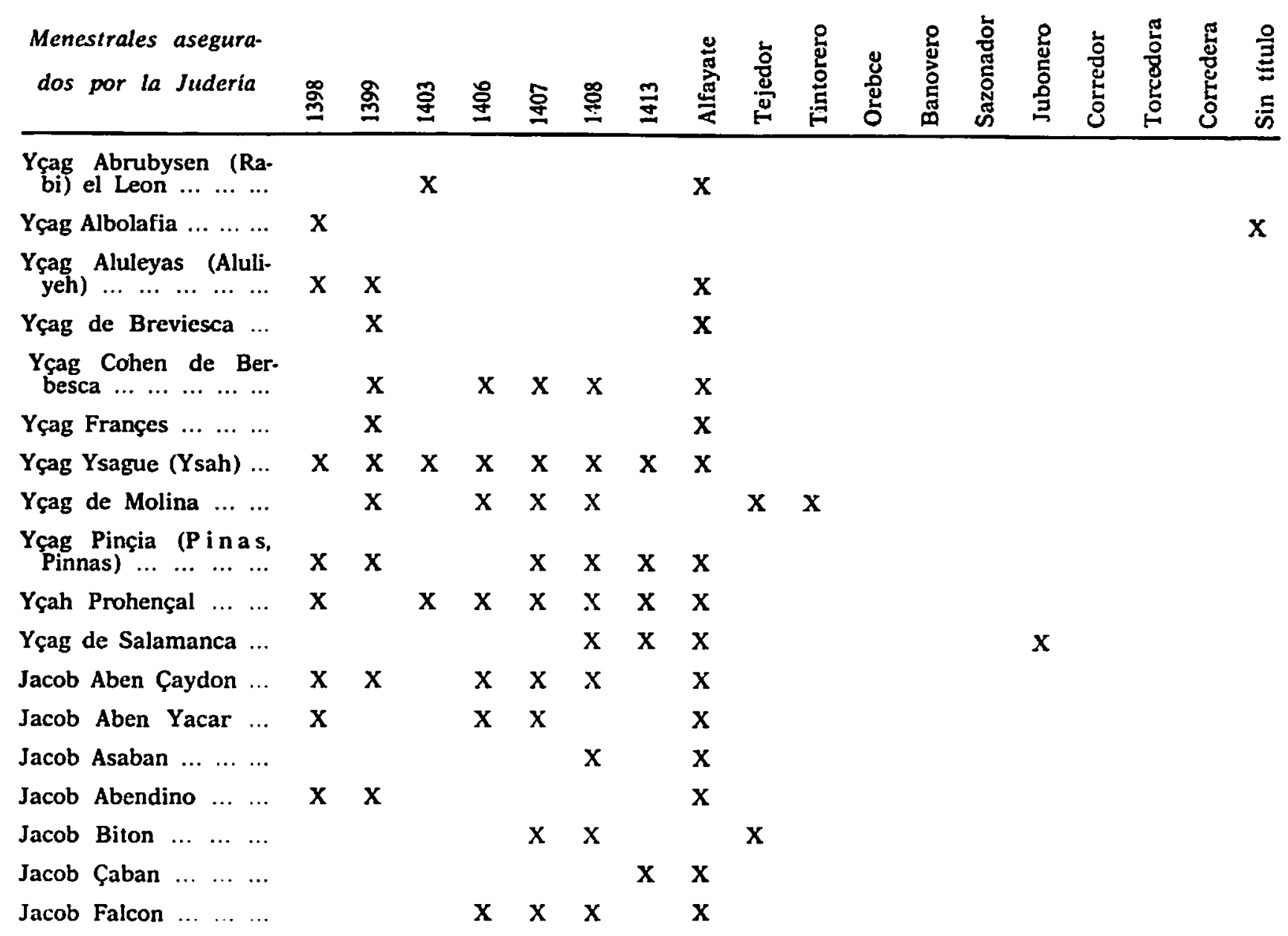




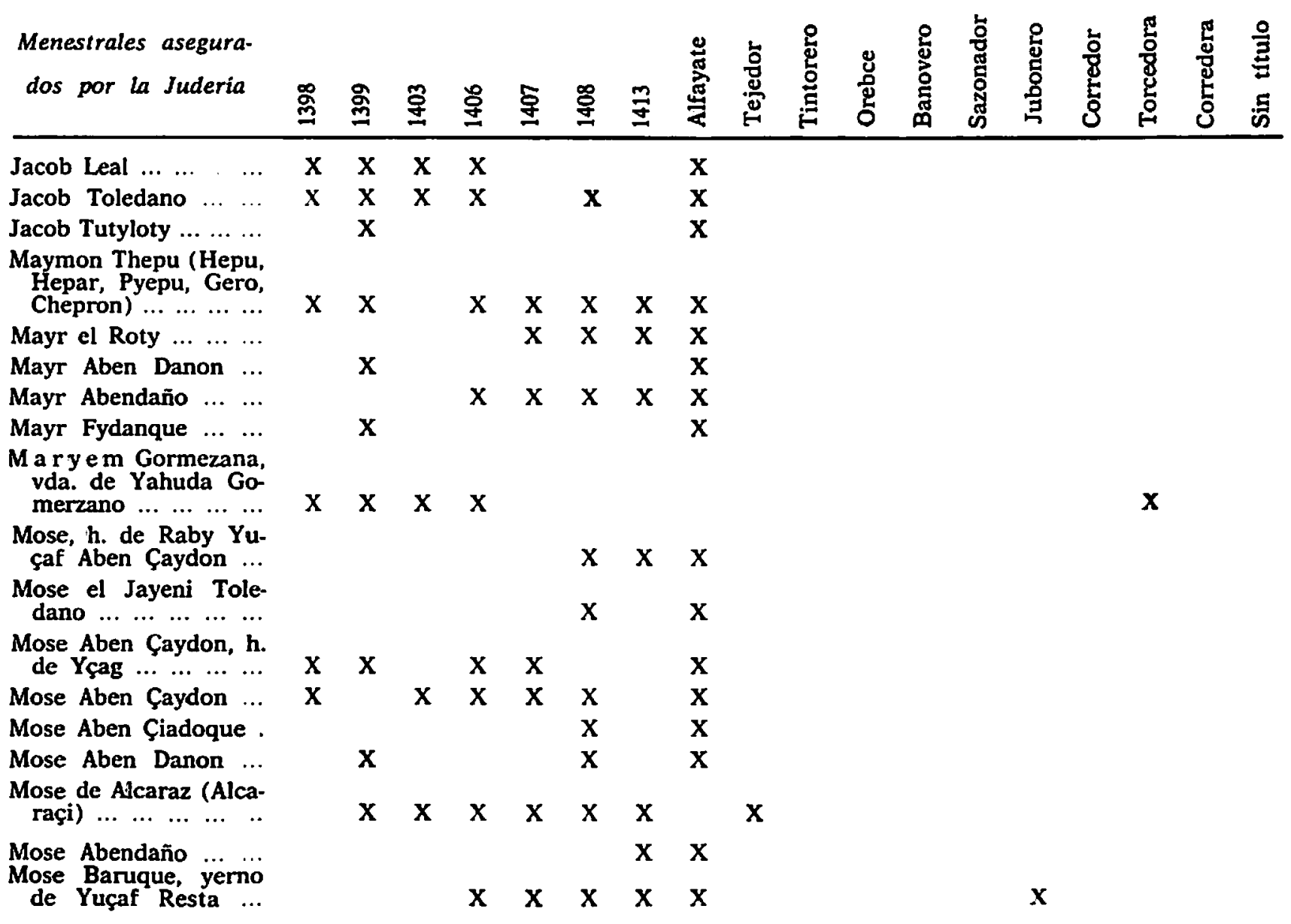




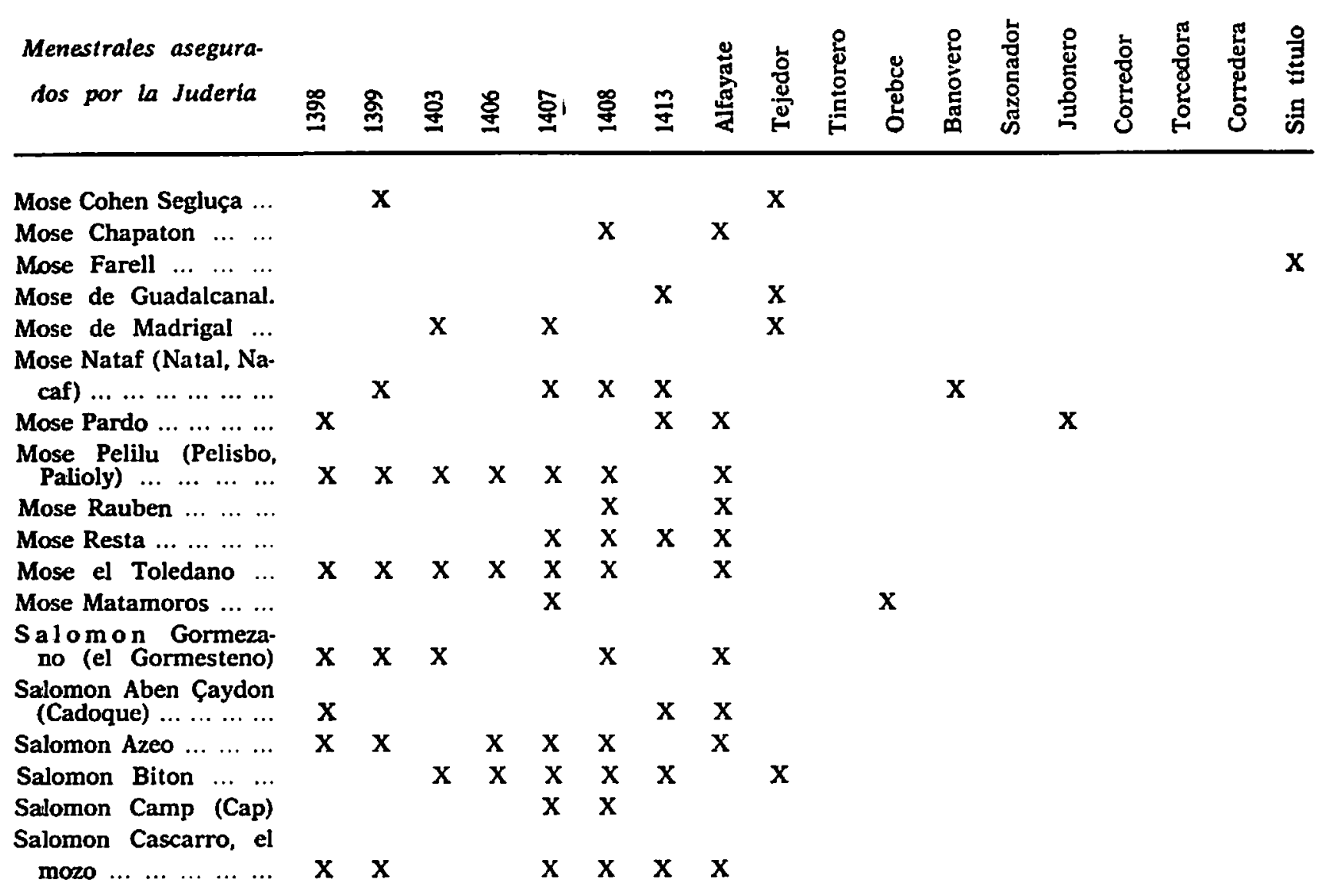




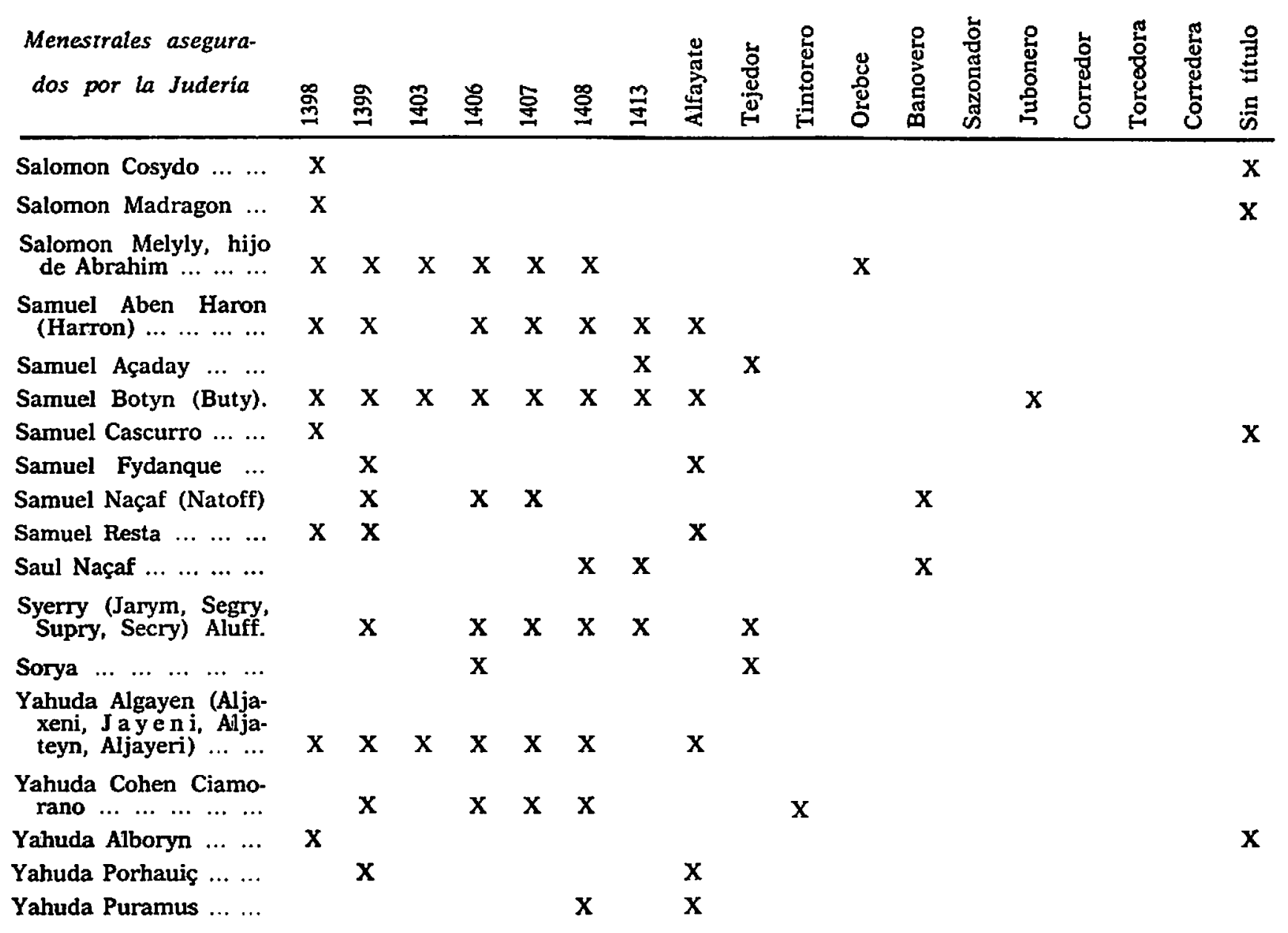




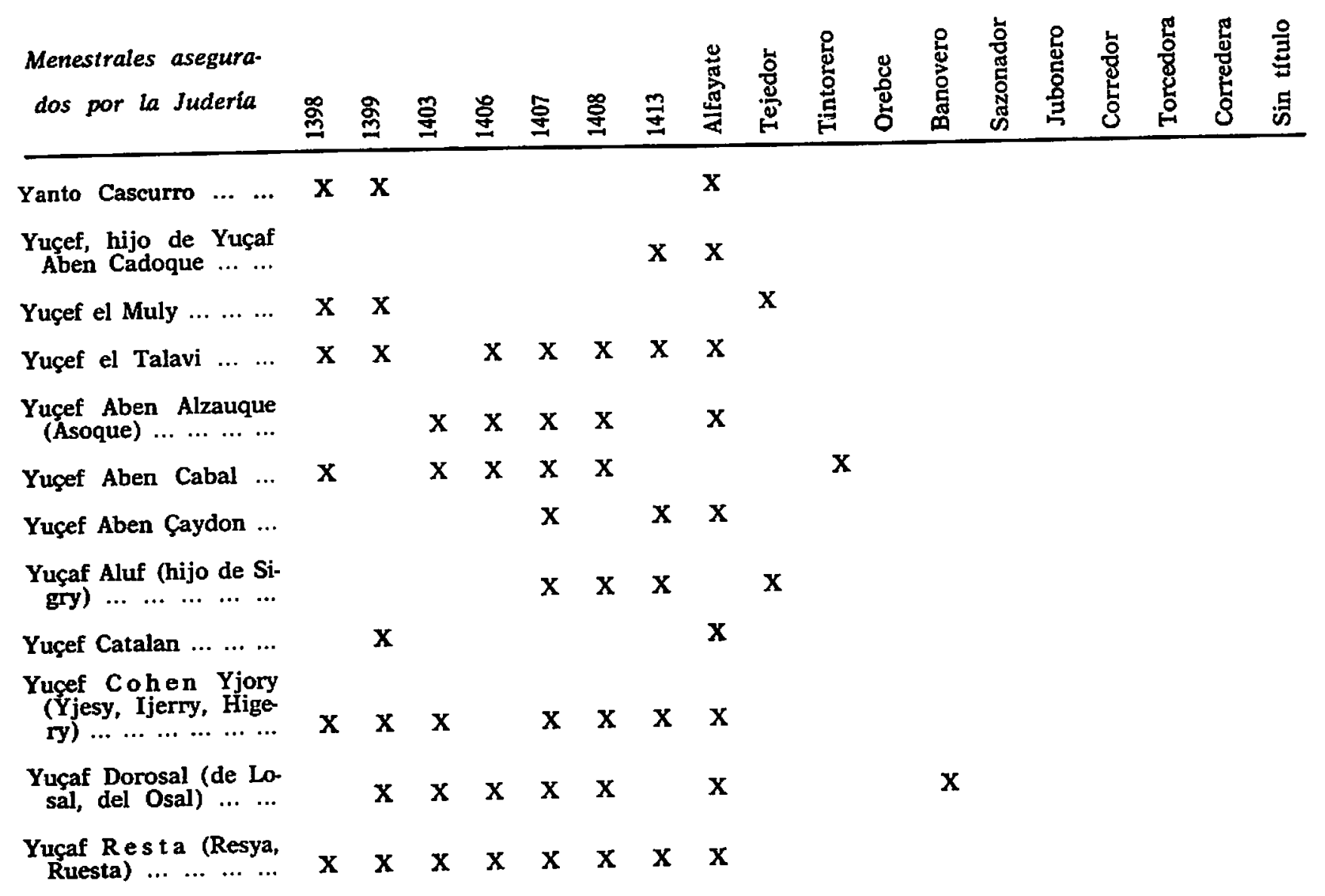




\section{II}

1391-9.29, Murcia. El concejo de Murcia al lugarteniente de baile de Orihuela. Solicitando la devolución de los bienes del Yahuda, herrero, vecino de Murcia.

Al honrrado Juan Castell, teniente lugar de bayle en la villa de Orihuela. El conçejo e ofiçiales e omes buenos de la noble, çibdat de Murçia vos enbiamos mucho saludar como aquel etc. Fazemos vos saber que paresçio ante nos Yahuda, judio, ferrero, morador en esta dicha ç:bdat e dixonos de como el conçejo e omes buenos de Callosa se avinieron con el dicho Yahuda que parase obrador e tienda en el dicho lugar de Callosa por tienpo de un año para usar de su ofiçio para aluçiar las rejas e prometieronle dar por cada un par de bestias que errasen una barchiella de trigo. El quel dicho Yahuda que fue al dicho lugar de Callosa e que levo alguna ferramienta e aparejos de su ofiçio, dello suyo e dello prestado, e puso e asento su tienda por el avenimiento sobredicho. E que servio el dicho año que prometio usar de su oficio en el dicho lugar de Callosa e aun bien un mes mas, e que quando oyo dezir del movimiento que se fazia contra los judios en el regno de Valencia, reçellando que si estudiera en el dicho lugar de Callosa que fuera muerto o apremiado de tornar christiano, que se vino aqui a la dicha sibdat, e que dexo en el dicho lugar de Callosa la dicha su ferramienta e aparejos, es a saber: martiellos e tenazas e otra ferramienta menuda e que enbio por ello por lo traer aqui a la dicha çibdat, onde aquel agora mora, e diz que non sabe por que nin por qual razon, Domingo Valdañana, vecino del dicho lugar de Callosa, en nonbre de vos, el dicho teniente lugar de bayle, diz que le enbargo e non dexo sacar del dicho lugar la dicha su ferramienta, seyendo cosa suya propia e della que tiene prestada, e non deviendo aquel nin entendiendo dever cosa alguna porque la dicha su ferramienta le devie ser enbargada. E pidionos que le mandasemos dar nuestra carta de ruegos para vos, dicho teniente lugar de bayle, en la dicha razon. E nos mandamos ge la dar, por la qual ros el dicho conçejo asignamos a vos el dicho Juan Castell, teniente 
lugar de bayle sobredicho, que tengades por bien de saber por qual razon fue enbargada la dicha ferramienta al dicho judio e si aquella le fue enbargada sin por que, que por onrra nuestra ge la mandedes tornar e desenbargar, e sy aquel alguna cosa deve al dicho lugar, diz que es presto de ge lo pagar como el dize que non entiende y dever cosa alguna, e que en caso que alguna poca cosa y deva, que mas deven a el que el non entiende dever a otro. E lo que ovieredes por bien de fazer sobre ello, rogamosvos que ayamos vuestra carta de respuesta. E de vos Dios salud. Fecha XXIX dias de setienbre.

\section{III}

1391-11-7, Murcia. El concejo de Murcia al de Alicante. Solicitando la devolución de los bienes de Yanto Aseo, judio, orfebre, vecino de Murcia.

A los onrrados, el conçejo e bayle e omes buenos e ofiçiales de la villa de Alicante, nos el conçejo, cavalleros, escuderos, afiçiales e omes buenos de la noble çibdat de Murçia, vos enbiamos mucho saludar como aquellos para quien querriamos que diese Dios mucha onrra e buena ventura. Fazemos vos saber que paresçio ante nos Yanto Aseo, judio, morador en la juderia desta çibdat, e dixonos quel, estando e morando en la villa de Elche e labrando de su ofiçio de orebze, que vos el dicho conçejo que enbiastes por el para que fuese a la dicha villa de Alicante a labrar del dicho su ofiçio en algunas cosas que lo aviades mester que era pro e onrra e serviçio de vos el dicho conçejo, e prometiestele, segund que aquel dize, que le fariades ayuda e le pagariades bien su trabajo, e diz quel dicho Yanto, judio, por obedezer vuestro mandado que le plugo por vos fazer onrra e serviçio de yr al dicho lugar de Alicante por vos servir de su ofiçio en todo lo que ovieredes menester. E diz que luego a pocos dias fue a la dicha villa de Alicante e levo consygo algunas ferramientas e aperos de su ofiçio e diz que estudo bien tres meses en la dicha villa de Alicante labrando e afanando de su ofiçio 
por mandado de vos el dicho conçejo de dia e de noche faziendo algunas feguras e ymagenes quel mandaran fazer los maestros e aquellos que entendien en el arte, que diz que avian de sacar agua encantada que estava açerca del camino de la dicha villa de Alicante. E diz que le prometiestes sy la dicha agua sallia, que le dariades por su afan çinquenta florines e si la dicha agua non sallie quel pagariades bien su trabajo. E estando asi afanando en la dicha labor en vuestro serviçio, diz que acaesçio el movimiento en el regno de Valençia e en toda la tierra que fazian tornar por fuerça a los judios christianos, e quel dicho Yanto de que oyo dezir que ovo reçelo quel matarian o quel farian tornar christiano por fuerça, e que ovo de foyr de la dicha villa de Alicante e se vino a la dicha çibdat de Murçia, e diz que dexo y en la dicha villa de Alicante la ferramienta e aperos del su ofiçio. E otrosi, diz que dexo dos hopas, la una de Mellinas celesty e la otra clara de paño de la tierra, e seys cabeçales de lana e dos savanas e unos manteles e unos tovajones, e como quier que diz quel dicho Yanto enbio a la dicha villa de Alicante por la dicha su ferramienta e ropa, diz que ge la non quisiestes dar nin le quisiestes pagar el su salario del afan que avia pasado en vuestro serviçio por su cuerpo e por sus manos, el qual salario en uno con la plata e plomo e aranbre e otros cosas suyas que diz que puso en la dicha lavor, diz que lo estima en XXX florines de Aragon poco mas o menos, e pidio e requirionos que le mandasemos dar nuestra carta de ruegos para vos en esta razón, en que toviesedes por bien de le tornar o mandar tornar desenbargadamente la dicha su ferramienta e ropas e paños de vestir e otras cosas que y dexo e que le fizieredes pagar los dichos $\mathrm{XXX}$ florines que diz que ha de aver por el salario del dicho trabajo de su cuerpo e plata e plomo e aranbre que diz que y puso de lo suyo. E nos mandamosle dar esta nuestra carta de ruegos para vos, el dicho conçejo, bayle e omes buenos e ofiçiales en la dicha razon. Por la qual vos rogamos que tengades por bien e por onrra de nos el dicho conçejo, que mandades desenbargar e tornar al dicho Yanto Aseo, judio, orebze, la dicha su ferramienta e aparejos del su ofiçio, e paños de vestir e la otra ropa que ay dexo quando aquel se vino desde. $E$ otrosi, que tengades por bien que le fagades pagar los dichos XXX florines que aquel dize 
e estima valer que puede montar el su salario, trabajo e afan que ay diz que puso en uno con la plata e plomo e aranbre e otras cosas que diz que puso de lo suyo o aquello que en vuestras conçiençias vos entendieredes que mereçe por su trabajo del tienpo que vos sirvio e de lo suyo que y puso como dicho es. E faredes en ello derecho e lo que devedes e nos gradeçer vos lo hemos mucho, ca en semejantes cosas e mayores fariamos nos por vos en todo lo que vuestra onrra fuere. E de lo que ovieredes en talante de fazer sobre ello, rogamos vos que tengades por bien de nos enbiar vuestra respuesta. E de vos Dios salud. Fecha siete dias de noviembre año de mill e trezientos e noventa e un años.

\section{IV}

1408-X-25, Valladolid. Juan II prohíbe a los judios intervenir o participar de alguna forma como recaudadores, fieles, fiadores, arrendadores o cogedores de las rentas reales. (AMM. Cart. 1391-1412, fols. 70-71.)

Don Juan por la graçia de Dios rey de Castilla, de Leon, de Toledo, de Gallizia, de Sevilla, de Cordova, de Murçia, de Jaen, de los Algarves, de Algezira e señor de Vizcaya e de Molina, a vos los del mi consejo e a los oydores de la mi audiençia e a vos los mis contadores mayores e alcalles e alguaziles e notarios de la mi corte e a los maestres de las ordenes, priores, comendadores e suscomendadores, alcaydes de los castillos e casas fuertes e llanas e a todos los concejos e alcalles, jurados, juezes, justiçias e otros ofiçiales qualesquier de todas las çibdades, villas e lugares de los mis reynos e señorios, e a qualesquier otras personas de qualquier ley o estado o condiçion que sean que agora son o seran de aqui adelante, e a qualquier o a qualesquier de vos que esta mi carta fuere mostrada o el traslado della signado de escrivano publico, salud e graçia.

Sepades que por quanto segund la ley de las Partidas es como sacrilejo en dar poder a los judios sobre los cristianos de los judgar o de 
tomar los portadgos e fazerlos cogedores e recabdadores de las otras rentas que an a dar los cristianos a los señores de la tierra o arrendargelas, que por razon destas cosas toman poder sobre ellos e an ocasion de fazerles muchos tuertos e agravios en muchas cosas, de lo qual viene muy grant deserviçio a Dios e a mi muy grand daño e a los mis regnos. Por ende, yo queriendo remediar e proveer sobre ello, entendiendo que cunple a mi serviçio e bien de mis reynos que las leyes de las dichas Partidas e otros derechos que sobresta razon fueron ordenados sean guardados, e porque es notorio manifiesto e paresçe de cada dia por esperiençia el grand daño que por la dicha razon viene a los dichos mis reynos e al bien publico dellos por ende, es mi merçet que ningund judio de qualquier estado o condiçion que sea, non sea osado de arrendar nin arriende ninguna renta nin pecho nin derecho que los dichos mis reynos me oviere a dar este año de la data de esta mi carta nin de aqui adelante en cada año en qualquier manera, asy rentas de alcavalas como de monedas e diezmos e portadgos, nin otras rentas algunas, nin sean fieles nin cogedores dellas, nin sean fiadores de ninguna persona en ellas en ninguna manera en publico nin en escondido, nin eso mismo arrienden rentas algunas de los diezmos o de otros qualesquier derechos que en los arçobispados e obispados e a los dichos maestres e otros qualesquier señores por sus vasallos o subditos en lo tenporal o en espiritual les sean devidos o se deviesen, nin sean fiadores nin cogedores nin recabdadores en los dichos derechos e rentas e sy los arrendaren o cojeren o recabdaren o fablaren en ellos en publico o en escondido para dar arrendar o cojer o recabdar, asy en renta como en fieldat o en otra qualquier manera, o fueren fiadores de otra persona alguna en ellas, seyendole provado que pague otra tanta quantia como es la renta, e sy sus bienes non valieren tanto que los pierdan todos e demas que les den çinquenta açotes publicamente e es mi merçet que la proeva se faga contra el tal jodio con dos jodios o con un jodio e un cristiano o con dos cristianos o por su confesion del dicho jodio e otrosy es mi merçet que sy algun cristiano diere parte en qualquier e las dichas rentas a qualquier jodio o le fiziere recabdador dellas e fuere en fabla o en confesión de ge la dar o consintiere en qualquier manera 
que los dichos jodios arrienden o recabden o resçiban o entren en la renta o en fialdat o en otra qualquier manera las dichas rentas o algunas dellas o fueren fiadores de los dichos jodios en ellas, quel tal cris. tiano seyendole provado por dos cristianos o por su confesión que pague otra tanta quantia como es la dicha renta e sy sus bienes non valieren tanto que los pierda todos e demas syerva un año en qualquier de los castiellos fronteros que declarere la justiçia que esto oviere de librar; destas penas sobredichas que aya la terçia parte qualquier del pueblo que acusare a los dichos jodios e cristianos que non guardaren lo contenido en esta mi ordenança, la otra terçia parte que sea para la justiçia que lo oviere de librar, la otra terçia parte que sea para la mi camara porque esto sea mejor guardado e conplido ruego a la reyna doña Catalina, mi señora e mi madre, e al infante don Ferrando, mi tio, e mis tutores e regidores de los mis reynos, que en sus çibdades e villas e lugares fagan guardar e conplir esta dicha mi ordenança e mando a vos, las justiçias e conçejos e ofiçiales e a todas las otras personas susosdichas e a cada uno de vos en vuestros lugares e jurediçiones que guardedes e cunplades e fagades guardar e conplir todo lo suso en esta mi carta contenido e cada cosa e parte della, que non arrendedes nin consyntades arrendar nin cojer nin recabdar asy en rentas como en fialdat nin en otra manera qualquier a ningunt jodio algunas nin ningunas rentas nin portadgos nin derechos nin otras pechos nin rentas nin derechos que los dichos mis reynos me ayan a dar o me pertenesçe en qualquier manera so las penas suso contenidas e fagades luego pregonar publicamente por las plaças e mercados acostumbrados de cada una de las dichas çibdades e villas e lugares todo lo contenido en esta mi carta porque todos los sepan e lo guarden e non puedan alegar ynnorançia que lo non sopieron, pero es mi merçet que por quanto este año en que estamos los dichos jodios tienen arrendadas algunas rentas o son recabdadores o cogedores dellas por las quales me podrian poner descuento que esta mi carta e todo lo en ella contenido se guarde e cunpla e fagades guardar e conplir desde el día que se sallesen las rentas e recabdamientos que los dichos jodios tienen en adelante para sienpre; e los unos nin los otros ron fagades nin fagan ende al so pena de la mi merçet e de diez mill 
maravedis a cada uno para la mi camara e de las penas suso contenidas. Dada en la villa de Valladolid a veynte e çinco dias de otubre año del nasçimiento del nuestro Salvador Jhesuchristo de mill e quatroçientos e ocho años. Yo la reyna. Yo el infante. Yo Pero Alfonso la fiz escrivir por mandado de los dichos señores reyna e infante, tutores de nuestro señor el rey e regidores de sus reynos.

1409-2-20, Valladolid. Juan II ordena el proceso de dos judios murcianos acusados de usura. (AMM. Cart. 1391-1412, fol. 82.)

Don Johan por la graçia de Dios rey de Castilla etc. a vos don Abrahyn Alfatex a Aben Juga espeçiero, judios vezinos de Murçia, e a qualquier de vos a quien esta mi carta fuere mostrada o el traslado della signado de escrivano publico, salud e graçia.

Sepades que por parte del mi procurador fiscal e promotor de la mi justiçia me fue dicho e denunçiado que vosotros e cada uno de vos non temiendo a Dios nin a mi nin a la mi justiçia nin a las penas que por ello meresçiades, que aviades dado e dades de cada dia publicamente a logro, conviene a saber: trigo e çevada e paños e dineros e otras cosas qualesquier a qualesquier personas e despues del ordenamiento quel rey don Enrrique mi padre e mi señor que Dios perdone fizo e ordeno, por lo qual diz que cayestes e sodes caydos en muy grandes penas creminales $\epsilon$ çeviles, e que señaladamente sodes tenudos de perder todo lo que asy avedes dado e prestado a logro e que lo ayan las personas a que lo asy prestastes e demas que devedes dar e pagar de vuestros bienes e de cada uno de vos al tanto como montan en lo que asy diestes a logro para la mi camara, en lo qual dize que avedes dado asy a logro desde tres años a esta parte fasta en quantia de çient mill maravedis cada uno de vos, los quales dize que pertenesçen a la mi camara, e dize que por quanto el es mi ofiçial e anda aqui en la mi corte continuadamente en mi ser- 
viçio, e otrosy, por quanto el dicho pleito perenesçe a mi a al mi [en blanco] es myo de oyr e de librar, por ende que vos lo quiere demandar por la mi corte, e pidiome por merçet que le mandase dar mi carta de enplazamiento para vos sobre la dicha razon, e yo veyendo que me pedia justiçia tovelo por bien. Porque vos mando, que del dia que vos esta mi carta o el dicho su traslado signado como dicho es vos fuere mostrada e leyda en vuestras personas sy pudieredes ser avidos, si non delante las puertas de vuestras moradas a do mas continuadamente vos soledes acoger faziendolo saber a vuestras mugeres e fijos sy los avedes o a dos vuestros vezinos mas çercanos que vos lo digan e fagan saber en manera que venga a vuestra notiçia porque non podades allegar ygnorançia, fasta quinze dias primeros siguientes parescades ante mi en la mi corte a conplir de derecho al dicho mi procurador fiscal e promotor de la mi justiçia sobre la dicha razon e non fagades ende al por alguna manera so pena de la mi merçet e de dos mill maravedis para la mi camara e de como esta mi carta vos fuere mostrada o el dicho su traslado signado como dicho es e la cunplades mando so la dicha pena a qualquier escrivano publico que para esto fuere llamado que de ende al que vos la mostrare testimonio signado con su signo porque yo sepa en como cunplides mi mandado. Dada en Valladolid, veynte dias del mes de febrero, año del nasçimiento del nuestro Salvador Jhesuchristo de mill e quatroçientos e nueve años. Yo Juan Gonçalez de Piña, escrivano de nuestro señor el rey la fiz escrivir por mandado de Juan Royz de Medina, Bachiller en decretos, alcalle del dicho señor rey en la su corte. Juan Rodriçi in decretos bacheilleris.

\section{VI}

1411-8-8, Ayllón. Carta de seguro real para los judíos de la aljama de Murcia. (AMM. Cart. 1412-29, fol. 2.)

Don Johan por la graçia de Dios etc. a vos don Ruy Lopez de Davalos, mi condestable de Castilla e mi adelantado mayor del reyno de 
Murçia, e a vos Garçia Ferrandez de Oterdelobos, lugarteniente en el dicho adelantamiento por el dicho mi condestable, e al conçejo e alcaldes e alguazil, cavalleros, regidores e omes buenos de la dicha çibdat de Murçia o a qualquier o a qualesquier de vos a quien esta mi carta fuere mostrada, salud e graçia.

Sepades que los jodios del aljama de la dicha çibdat se me enbiaron querellar e dizen que por quanto algunos frayles predicadores predicaron e fezieron y çiertos sermones que algunos vezinos desa çibdat e su tierra e comarca que estan escandalizados contra ellos por los meter a robo, otrosy, pora los matar o ferir e fazer otros muchos males e daños e desaguisados sin razon e sin derecho como non deven, diziendo que se tornen christianos por fuerça e contra la voluntad e levantandoles otros achaques, por lo qual diz que non osan andar seguramente por esa dicha çibdat e su tierra a librar sus faziendas, en lo qual dizen que si asy pasase que rescibirian grand agravio e daño, e enbiaronme pedir por merçed que les proveyese sobre ello como la mi merçed fuese, mandandoles dar mi carta de seguro en esta razon, porque ellos pudiesen bevir seguramente en esa dicha çibdat e andar por ella e por la dicha su tierra e comarca e por todas las otras partes de los dichos mis regnos e librar sus faziendas.

E yo, veyendo que me pedian razon e derecho, tovelo por bien, e por esta mi carta aseguro a los dichos judios e judias de la dicha aljama e a todos sus bienes e mando que les non consintades ferir e matar ni lisiar ni fazer otro mal ni daño ni desaguisado ni sinrazon alguna, ni les consintades tomar sus bienes por fiança e contra su voluntad syn razon e syn derecho como non deven. $E$ por este dicho mi seguro mejor les sea guardado e algunos non se atrevan a lo quebrantar diziendo que non fueron sabidores del, mandovos que lo fagades luego pregonar publicamente por las plaças e mercados acostumbrados desa dicha çibdat porque todos lo sepan e despues non puedan alegar ynorançia alguna e el pregon asy fecho, sy alguno o algunos fueren o pasaren contra el por lo quebrantar o menguar en alguna manera, pasad e proçeded con- 
tra ellos e contra cada uno dellos e contra sus bienes a las mayores porque todos lo sepan e despues non puedan alegar ynorançia alguna e por las leyes de ordenamientos reales fechas e establecidas en tal caso como contra aquellos que pasan e quebrantan seguro e mandado de su rey e de su señor natural, E los unos e los otros non fagades ende al for alguna manera so pena de la mi merçed e de diez mill maravedis para la mi camara a cada uno por quien fincar de lo asy fazer e con. plir, e de como esta mi carta vos fuere mostrada e los unos e los otros la cunplieredes, mando so la dicha pena a qualquier escrivano publico que para esto fuere llamado que de ende al que vos la mostrare testimonio signado con su signo porque yo sepa en como conplides mi mandado.

Dada en Ayllon, ocho dias de agosto, año del nasçimiento del nuestro señor Jhesuchristo de mill e quatroçientos e honze años. Yo Diego Fesrandez de Castro, escrivano de nuestro señor el rey la fiz escrivir por mandado de Diego Garçia de Sant Roman, liçençiado en Leyes e de Garçia Sanchez del Castillo, alcalles del dicho señor rey en la su corte. Didacus. Garsie Liçençiatus Registrada.

\section{VII}

1412-10.18, Murcia. Acuerdo concejil prohibiendo al alguacil intervenir dentro de la judería y perturbar la vida de sus vecinos.

E por quanto en el dicho conçejo fue dicho e querellado por el aljama de la juderia de Murçia, que la dicha aljama reçebia muy muchos Inales e agravios e synrazones del alguazil de la dicha çibdat, espeçialmente los jodios que moran en la call de la carnesçeria por razon que cada que el dicho alguazil pasa por la dicha calle para sallir a la casa de la moneda e falla a algunos jodios posados a sus puertas que les faze ençerrar en sus casas e si les falla algunas armas, tiragelas. E otrosy, porque ay algunos jodios menestrales, asy çapateros como texedores 
€ alfayates e borratheros e de otros ofiçios, los quales por fuerça por dar recabdo cada unos de sus ofiçios se an de levantar de noche e han de tomar lunbre de las unas casas a las otras e si el dicho alguazil los falla, tomalos presos e levalos a la prision. E otrosy, sy falla las puertas de la juderia abiertas e entra dentro e toma las armas a algunos de los jodios e quierelos levar a la prision o los prenda e les faze otras synrazones non devidamente, sabiendo bien el dicho conçejo que es contra derecho e contra costunbre e uso antiguo fasta aqui usado e acostunbrado de tanto e tan luengo tienpo aca que memoria de omes non es en contrario e que pedian por merçed al dicho conçejo, cavalleros, escuderos, ofiçiales e omes buenos que mandasen al dicho alguazil que pues este fecho era asy, que se non entremetiesen de aqui adelante de yr nin de pasar contra lo que dicho es. E el dicho conçejo, cavalleros, escuderos, ofiçiales e omes buenos, oydo lo que dicho es, e otrosy, seyendo çiertos que los dichos jodios estando en su juderia que el dicho alguazil que non ha que ver con ellos en razon de las armas que traen nin de les vedar que non esten a sus puertas nin de les vedar que non salgan de noche a tomar lunbre unos jodios de otros sus vezinos, ordenaron e mandaron al dicho alguazil que de oy adelante non les fagan las dichas cosas, pero sy fuera de la juderia los fallase o de fuera de las sus calles de noche que pasen contra ellos segund que fasta aqui los otros alguaziles de la dicha çibdat pasaron en los tienpos pasados.

\section{VIII}

1413-1-20. Guadalajara. Juan II designa a Juan Sánchez Manuel y Fernán Pérez Calvillo para delimitar la judería de Murcia. (AMM. Cart. 1412-29, fol. 2.)

Don Juan por la graçia de Dios etc. a vos don Johan Sanchez Manuel e Ferrand Calvillo, vezinos de la çibdat de Murçia, salud e graçia. Sepades que por quanto en el ordenança que yo fize en razon de como avian e han de usar e bevir los judios e judias en la provinçia del rey 
de Aragón, mi muy oaro e muy amado tio, mi tutor e regidor de los mis regnos, se contiene que todos los dichos judios e judias vivan apartados de los christianos e christianas en un çirculo aparte de la çibdat, villa o lugar donde fueren vezinos, e que sean çerradas las calles e las puertas en derredor en guisa que todos las puertas salgan al dicho çirculo e en el dicho çirculo aya una puerta por do se mande e non mas e que en el dicho çirculo moren los dichos judios e judias e non en otro lugar, el qual dicho lugar e çirculo les deve ser apartado por dos omes buenos discretos de cada çibdat o villa o lugar que les yo nonbrare segund que mas largamente en la dicha mi ordenança se contiene. $E$ porque sodes tales que guardaredes mi serçicio e vuestras conçiencias en esta parte, es mi merçed que vos los sobredichos Juan Sanchez Manuel e Ferrand Calvillo, ayuntadamente e non el uno syn el otro, apartedes e señaledes del dicho lugar e çirculo a los judios e judias vezinos e moradores en la dicha çibdat de Murçia e de la su tierra, segund e en la manera que en la dicha mi ordenança se contiene. Porque vos mando que luego vista esta mi carta lo fagades e cunplades asy segund susodicho es e pongades luego deligencia por quanto asy cunple a mi serviçio, ca yo vos do poder conplido para ello. Otrosy, por esta mi carta mando al conçejo e alcalles e alguazil e cavalleros, escuderos, regidores, oficiales e omes buenos de la dicha çibdad de Murçia que vos non enbargue nni contrallen nin vos pongan enbargo nin contrallo alguno en ello, antes les mando que vos den todo el favor e ayuda que de mi parte les dixeredes que avedes menester para fazer e conplir lo que dicho es, e los unos nin los otros non fagades nin fagan ende al por alguna manera so pena de la mi merçed e de diez mill maravedis a cada uno para la mi camara por quien fincar de lo asy fazer e conplir. Dada en la villa de Guadalfajara, veynte dias del mes de enero, año del nasçimiento del nuestro salvador Jhesuchristo de mill e quatroçientos e treze años. Yo Alvar Garçia de Vadillo la fiz escrivir por mandado de nuestro señor el rey por quanto asy fue acordado en el su consejo. Conde Seguntinus. Per Afan. Cartaginensis. Petrus Sancii, legun dotor. 


\section{IX}

1413-2-14. Murcia. Acuerdo concejil dejando sin efecto lo dispuesto por los comisionados reales y ordenando la reposición de las puertas de la judería.

En el dicho conçejo fue dicho que Ferrand Perez Calvillo e por Juan Sanchez Manuel avian tirado las puertas de la juderia e fecho mandamiento a la aljama de los jodios que dexasen e desanparasen la dicha juderia, la qual era çercada e situada desde que Murçia es de christia. nos es juderia apartada e situada, lo qual era fecho contra la ordenanza fecha por el rey nuestro señor. Por ende, ordenaron e mandaron que los jurados requieran de parte del dicho señor rey a los dichos Juan Sanches Manuel e Ferrand Perez que en este fecho non se entremetan ha entrar cosa alguna, por quanto el dicho conçejo entiende desto aperçebir al rey nuestro señor e de le dar ha entender este fecho, porque e] dicho señor rey provea sobre ello como la su merçed fuere, e otrosi, que tornen e manden tornar las puertas a la dicha juderia porque aquella este çerrada e non sea ocasyon de ser robada e destroyda, protestando que sy non lo fizieren e la dicha juderia reçibiere mal nin dapno o fuere robada o destroyda, que el rey nuestro señor ge lo pueda demandar de como la su merçed fuere, e sy por ventura los sobredichos non quisieren çesar de fazer las cosas sobredichas, que demandavan a los alcaldes e alguazil e jurados que fasta tanto que el señor rey fuere requerido a los dichos negoçios, que porque la dicha juderia non fuere robada que fizieren tornar las dos puertas de la dicha juderia e las haga sentar sus puertas porque la dicha juderia estudiere enguardada segund dicho es.

\section{$\mathrm{X}$}

1415-2-9, Murcia. Acuerdo concejil dejando sin efecto el contrato suscrito por la aljama de los jodios con el adelantado y Fernan Calvillo. 
Por quanto en el dicho conçejo fue dicho que los judios de la aljama de la dicha çibdat por algunas cosas e contrastos que avian acaesçido entrellos que por tracto de algunas de los dichos jodios que avian fecho un contracto e conpusiçion en tal manera que avian puesto e ordenado entrellos que qualquier o qualesquier querellas que un jodio oviese de otro, que fuesen juezes el adelantado e Ferrand Calvillo, en tal manera que todo lo que ellos judgasen entre los dichos jodios que ellos lo avian por firme. E por quanto la tal ordenaçion era e es fecha contra las ordenanças fechas por el rey nuestro señor en este caso, por ende, ordenaron e mandaron a Juan Ferrandez de Villaverde que vaya a la aljama de los dichos judios e les mande que para el martes primero que viene traygan la dicha ordenacion e poderio que dieron al dicho adelantado e al dicho Ferrand Calvillo, so pena de seysçientos maravedis e la pena sy en ella cayeren e non la traxeren que los jurados la esecuten en ellos e la guarden para que fagan della lo que fuere merçed del dicho conçejo. 